\title{
Protective role of the lung collectins surfactant protein $A$ and surfactant protein $D$ in airway inflammation
}

\author{
Angela Haczku, MD, PhD \\ Department of Medicine, University of Pennsylvania.
}

\begin{abstract}
The acute inflammatory airway response is characterized by a time-dependent onset followed by active resolution. Emerging evidence suggests that epithelial cells of the proximal and distal air spaces release host defense mediators that can facilitate both the initiation and the resolution part of inflammatory airway changes. These molecules, also known as the hydrophilic surfactant proteins (surfactant protein [SP]-A and SP-D) belong to the class of collagenous lectins (collectins). The collectins are a small family of soluble pattern recognition receptors containing collagenous regions and C-type lectin domains. SP-A and SP-D are most abundant in the lung. Because of their structural uniqueness, specific localization, and functional versatility, lung collectins are important players of the pulmonary immune responses. Recent studies in our laboratory and others indicated significant associations of lung collectin levels with acute and chronic airway inflammation in both animal models and patients, suggesting the usefulness of these molecules as disease biomarkers. Research on wild-type and mutant recombinant molecules in vivo and in vitro showed that SP-A and SP-D bind carbohydrates, lipids, and nucleic acids with a broad-spectrum specificity and initiate phagocytosis of inhaled pathogens as well as apoptotic cells. Investigations on gene-deficient and conditional overexpresser mice indicated that lung collectins also directly modulate innate immune cell function and T-cell-dependent inflammatory events. Thus, these molecules have a unique, dual-function capacity to induce pathogen elimination and control proinflammatory mechanisms, suggesting a potential suitability for therapeutic prevention and treatment of chronic airway inflammation. This article reviews evidence supporting that the lung collectins play an immune-protective role and are essential for maintenance of the immunologic homeostasis in the lung.
\end{abstract}

\section{Keywords}

Macrophage; dendritic cell; surfactant; SP-D; SP-A; innate immune regulation

The pulmonary immune system is faced with the dual task of elimination of inhaled pathogens and maintenance of an inflammation-free mucosal environment. Although physical barriers filter out most of the inhaled material, a large amount of small, potentially toxic, infectious or allergenic particles $(<5 \mu \mathrm{m}$ in diameter) still reaches the distal air spaces, 
where they encounter components of the innate immune system. Under normal, nondiseased conditions, these include the alveolar macrophages, dendritic cells, and lung collectins.

\section{DISCOVERY OF THE IMMUNE REGULATORY AND PATHOGEN SENSING ACTIVITIES OF THE LUNG COLLECTINS: A HISTORICAL PERSPECTIVE}

Lung collectins were originally identified as surfactant associated proteins. Surfactant, a phospholipid material that lines the airliquid interface in the distal air spaces, was discovered by Clements and colleagues ${ }^{1,2}$ in the early 1960s. To date, 4 unique proteins have been found related to surfactant: surfactant protein (SP)-A, SP-B, SP-C, and SP-D. The small, hydrophobic molecules SP-B and SP-C are essential in the structural organization of surfactant and maintenance of low surface tension. On the other hand, SPA and SP-D, the focus of this review, are large, hydrophilic molecules with host defense and immune regulatory functions.

SP-A was discovered by King et $\mathrm{al}^{3}$ in 1973 and was termed a surfactant protein because of its close association with pulmonary surfactant. By the mid 1980s, cDNA and genomic sequencing revealed that, unlike SP-B and SP-C, SP-A contains collagenous sequences. ${ }^{4-7}$ SP-D was described in 1988 as a collagenous glycoprotein ${ }^{8}$ with primary sequence similarities to SP-A. In 1989, Tenner et $\mathrm{al}^{9}$ showed that the triple-helical collagen structure of purified SP-A is strikingly similar to the structure of the first component of complement $\boldsymbol{C l q}$ and that it could mediate phagocytosis through the C1q-receptor by monocytes/ macrophages. ${ }^{10}$ The $\mathrm{C} 1 \mathrm{qR}$ was later shown to be identical to cell surface calreticulin-a multifunctional, low-affinity, and high-capacity calcium-binding and inactivating protein with various chaperone functions - and to recognize the amino terminal collagen tail of SPA, SP-D, and other collagenous lectin structures. ${ }^{11-13}$ Although binding to calreticulin did not explain all their (the lung collectins SP-A and SP-D) biological activities, these discoveries prompted a large array of studies into the capability of SP-A and SP-D to modulate innate immune cell function directly.

Amino acid sequencing studies in the late 1980s also demonstrated a remarkable homology of SP-A with soluble mannosebinding proteins and revealed residues common to the carbohydrate recognition domains (CRDs) of other mammalian lectins. ${ }^{14,15}$ Although the first collagenous lectin (collectin), bovine conglutinin was discovered more than 100 years ago, the significance of carbohydrate recognition was recognized only in the 1950s (reviewed by Gupta and Surolia ${ }^{16}$ ). The first direct demonstration of lectin-mediated binding of SP-D to gram-negative bacteria and resultant bacterial aggregation was published in 1992 by Kuan et al, ${ }^{17}$ suggesting possible roles for collectins in pulmonary host defense. The capability to recognize carbohydratemoieties differentially on pathogen surfaces is today considered an important common function of all collectins.

Together with conglutinin, to date 9 different members have been identified in the collectin family: mannose-binding lectin (MBL), SP-A, SP-D, collectin (CL)-43, CL-46, CL-P1 (placenta), CL-L1 (liver), and CL-K1 (kidney). In spite of structural similarities, C1q does not show C-type lectin activities and is not considered a collectin. MBL, conglutinin, CL-43, CL-46, CL-K1, SP-A, and SP-D are secreted extracellularly, whereas CL-L1 and CL-P1 are 
nonsecreted collectins. With the exception of conglutinin, CL-43, and CL-46 (which were only found in cattle ${ }^{18}$ ), collectins are widely distributed among different species. MBL and CL-L1 are produced by the liver, and CL-K1 is found in most organs. CL-P1 is released by the placenta, whereas the majority of SP-A and SP-D is synthesized in the distal airways. Each of these molecules can be detected in the human serum.

Collectins form oligomeric structures similar to the ficolins (L-ficolin, M-ficolin, and Hficolin) and adiponectin, relatively recently identified members of the C-type lectin and defense collagen superfamilies (see reviews ${ }^{13,19-21}$ ). On pathogen recognition, C1q, MBL, and the ficolins are capable of initiating the complement activation pathway. However, unlike $\mathrm{C} 1 \mathrm{q}$, which is the first component of the classic complement cascade, MBL and ficolins initiate the complement system through attached MBL-associated serine proteases. Binding to lectins by MBL and ficolins triggers activation/cleavage of $\mathrm{C} 4, \mathrm{C} 2$, and $\mathrm{C} 3$ without the presence of C1q. ${ }^{13,22-24}$ This third type of complement activation pathway is called the "lectin pathway.",19

There is no indication so far that SP-A or SP-D could activate the complement system. ${ }^{25}$ Nevertheless, we have compelling evidence today that both of these collectins are potent cellular modulators of immune responses in the lung (see reviews ${ }^{26-29}$ ). The most recent piece of this evidence comes from studies on various genetically modified mice. In the late 1990s, mice lacking or overexpressing lung collectins were generated in several laboratories. ${ }^{30-35}$ Even though there were discrepancies related to the different background strains or the methods used for genetic manipulations, studies on SP-A and SP-D geneinactivated mice generally reported increased susceptibility to infectious agents, enhanced acute inflammatory response to pathogen exposure, and vulnerability to chronic inflammation. ${ }^{30,32,34-50}$

The relevance of these findings to human disease is supported by a high degree of evolutionary conservation among different classes of vertebrates. ${ }^{51,52}$ Given their specific localization to the proximal and distal airway epithelium, uniqueness of their structure, and functional versatility, SP-A and SP-D play immunoprotective roles at multiple levels. The following parts of this review discuss the innate immune role and regulation of lung collectins in the course of the inflammatory airway response.

\section{REGULATION OF SP-A AND SP-D EXPRESSION}

\section{The collectin gene}

The genes for SP-A and SP-D are clustered on the long arm of chromosome 10q22-23. ${ }^{53}$

The SP-D gene is linked to SP-A and is located proximally to the centromere at about 80 to $100 \mathrm{~kb}$ from the SP-A2 gene. The collagen-like sequences are encoded by several short exons. $5,14,54,55$ The overall length of the collagen domain in each specific collectin is determined by the number of tandem exon duplications. The intron-exon organization (1 intron is inserted between 2 exon duplicates) resembles the genes of nonfibrillar collagens, ${ }^{14}$ suggesting an evolutionary relationship. 
The neck domain and the CRD are each encoded by single discrete exons. The similar structure of the collectin genes indicates that they evolved by duplication from a common ancestral gene, which was probably formed by exon shuffling between genes encoding nonfibrillar collagens and a primordial lectin. ${ }^{42}$

\section{Cell- and tissue-specific SP-A and SP-D expression}

The majority of SP-A and SP-D is expressed on the luminal surface of the pulmonary epithelial cells (Fig 1, A and B). Although the most important source of SP-A and SP-D is the lung, ${ }^{56}$ transcripts for these molecules were also detected in mesothelial tissues (mesentery, peritoneum, and pleura), synovial cells, the eustachian tube and nasal sinuses, the gastrointestinal tract, and the genitourinary tract. ${ }^{56-62}$ The importance of extrapulmonary collectin expression was supported by studies showing that specific SP-A haplotypes differ between children susceptible to recurrent otitis media ${ }^{63}$ and that SP-D expression in the human gastric mucosa is significantly increased in Helicobacter pylori infection. ${ }^{64}$ Collectins were also demonstrated to enhance phagocytosis of chlamydial pathogens ${ }^{65}$ and to inhibit Chlamydia trachomatis infection (a frequent cause of infertility) in the female reproductive tract. ${ }^{66}$ SP-A and SP-D are detected in the amniotic fluid in large amounts (2-8 $\mu \mathrm{g} / \mathrm{mL}$ ) by 40 weeks of gestation ${ }^{67}$ and were suggested to play a role in protection from infections, inflammation, and initiation of parturition (see review ${ }^{27}$ ). Thus, nonsurfactantassociated expression of lung collectins in the proximal airways (Fig 1,C) and in mucosal surfaces of various organs indicates generalized host defense significance of these molecules. Importantly, collectin levels can be measured in serum and reflect the extent of lung injury. Thus, they may be used as biomarkers. ${ }^{68}$

\section{Transcriptional regulation of lung collectins during fetal lung development and airway inflammation}

Relatively short promoter sequences control cell/tissue-specific expression and developmental regulation of the surfactant protein genes, which are also influenced by transcriptional and/or posttranscriptional mechanisms affecting mRNA stability. Gene expression of the lung collectins during embryogenesis parallels increases of the surfactant phospholipids and the hydrophobic surfactant proteins (SP-B and SP-C). SP-D mRNA expression at 10 weeks of gestation precedes that of SP-A, ${ }^{69}$ but both collectins increase exponentially during the third trimester (see review ${ }^{27}$ ). Although surfactant protein promoter function depends on multiple transcription factors, thyroid transcription factor (TTF)-1 (Nkx2.1) appears to be a common positive regulator ${ }^{70,71}$ during lung development and under baseline conditions in the adult lung.

In response to inflammation and injury however, transcriptional regulation of SP-A and SP$\mathrm{D}$ appears to fall under differential regulatory pathways. SP-A protein levels transiently decreased during the allergic airway response in mice ${ }^{72}$ and in patients with asthma. ${ }^{73} \mathrm{In}$ contrast, SP-D protein levels increased in a time-dependent fashion, preceded by SP-D mRNA upregulation after allergen challenge ${ }^{74,75}$ (Fig 2, $A$ ). Although the mechanism is not well understood, differential SP-A and SP-D gene activation can be induced by cyclic AMP, ${ }^{69,76} \boldsymbol{I F N}-\gamma,{ }^{69,75}$ TNF- $\alpha$, TGF- $\beta$, and glucocorticoids. ${ }^{69,77}$ Because of a negative glucocorticoid response element in the SP-A1 promoter, SP-A is inhibited by 
glucocorticoids. Interestingly, there is no glucocorticoid response element in the $+3-\mathrm{kb}$ human SP-D 5' flanking sequence ${ }^{78}$ (Fig 2, D), yet there is a significant SP-D promoter activity in response to glucocorticoids. ${ }^{69,79}$ The significance of the differential transcriptional pathways probably is to ensure the possibility of a competent immune response in a wide variety of pathological conditions. In addition, selective regulation of SPA and SP-D would allow these collectins to exert specific functions, thereby reducing immune regulatory redundancy.

Lung collectins are upregulated during the T-cell-dependent allergic airway changes in BALB/c, C57BL/6, and 129J inbred mouse strains. ${ }^{74,80}$ Interestingly, both the baseline SPD expression level and the enhanced SP-D production in response to inflammation were selectively higher in C57BL/6 mice than in BALB/c mice ${ }^{81,82}$ These data indicated that a relative strain resistance to develop allergic sensitization and airway hyperresponsiveness ${ }^{83}$ is associated with an increased capability to produce SP-D and that promoter regulation of SP-D gene expression is genetically determined.

It is possible that specific upregulation of SP-D is induced by TH2-type cytokines in response to allergen challenge. Early support for a role of TH2 cytokines came from studies on mice overexpressing IL-4, ${ }^{84} \mathrm{IL}-5,{ }^{85}$ and IL- $13^{86}$ because these animals had markedly elevated SP-D expression in the lung. Direct cytokine regulation was confirmed in a type II alveolar epithelial cell culture system in which SP-D (but not SP-A) was enhanced by IL-4, ${ }^{79} \mathrm{IL}-13^{75}$ (Fig 2, $B$ and $C$ ), and IL-6. ${ }^{82}$

Sequence analysis of the SP-D gene promoter suggested potential regulatory roles for signal transducers and activators of transcription (STAT), CCAAT/enhancer-binding protein $(\mathrm{C} /$ EBP), activator protein-1 (AP-1), ${ }^{78,87,88} \mathrm{TTF}-1$, and nuclear factor of activated T cells $\left(\right.$ NFAT) ${ }^{71}$ binding sites (Fig 2,D). The AP-1 complexes ${ }^{87}$ and NFAT in cooperation with TTF- $1^{71}$ were shown to activate SP-D mRNA. These sites are clustered in the proximal SP$\mathrm{D}$ gene promoter and are well aligned among the murine, rat, and human sequences, indicating important, shared pathways in SP-D transcription. In addition to the AP-1/ NFAT/TTF cluster, the SP-D promoter contains binding sites for C/EBP. Apart from regulating tissue development and cell differentiation, these basic leucine zipper domain (bZip) class DNA-binding proteins are important for the regulation of the acute phase response. ${ }^{89-91} \mathrm{C} / \mathrm{EBP}(\mathrm{C} / \mathrm{EBPa}), \mathrm{C} / \mathrm{EBP} \beta$ (inducible nuclear factor of IL-6 [NF-IL6]), and C/EBP $\delta$ (NF-IL6- $\beta)^{92}$ are expressed by lung epithelial cells, and each of them was shown to induce SP-D transcription. ${ }^{88}$ Further, the mouse and rat promoter have an identical nonspecific STAT-binding site in a prominent location, proximal to the AP-1 site. This STAT-binding site has a nonspecific 5-base spacing motif ${ }^{93}$ and could mediate the effects of IL-4/IL-13 and IL-6. ${ }^{75,79,82}$ Although this site is missing from the human SP-D promoter, there are other STAT-like binding motifs both proximally and distally, indicating that the human SP-D gene can be regulated by cytokines that use either the C/EBP or STAT transcription pathways. IL-6 for instance, is known to use both pathways. ${ }^{94}$

Taken together, these studies indicate that the expression of lung collectins is regulated by multiple, complementary pathways that can result in significant changes in the local 
collectin levels. The extent of expression in turn influences the outcome of the inflammatory airway response.

\section{SENSING AND CLEARANCE OF PATHOGENS, ANTIGENS, AND APOPTOTIC BODIES}

\section{The collectin structure}

The significant functional complexity of collectins is based on their structural characteristics. Collectins contain 4 analogous regions: (1) CRD (also called C-terminal lectin or globular head), (2) the a-coiled neck, (3) the collagenlike domain, and (4) the cystein-rich $\mathrm{N}$-terminal ${ }^{20},{ }^{95-99}$ (Fig 3, A).

The collectins are assembled as trimeric subunits, which multimerize to varying degrees. The CRDs are held in trimeric arrays at the end of each collagenous stalk and are responsible for recognition of carbohydrate molecules commonly present on the surface of microbes or pollens but not usually found on mammalian cells. This common element of lectins is characterized by the presence of 14 invariant amino acid residues and 18 conserved residues, including 4 cysteine residues that form a conserved disulfide-bonding pattern. The CRDs have relatively low affinities for a single monosaccharide but have higher affinities for clustered oligosaccharides. ${ }^{100}$ Crystal structure analysis of maltose-bound recombinant fragments ${ }^{101,102}$ revealed the presence of a calcium ion located in the trimeric axis in a pore at the bottom of the funnel formed by 3 CRDs, close to the neck-CRD interface. ${ }^{96}$ Sequence alterations showed that presence of this calcium ion and the structural organization of the CRD are essential for a relative saccharide selectivity and the differential quaternary arrangement of the different collectins.

A short trimeric helical coil bridges the collagenlike arm to the globular CRD at the carboxy-terminal domain of the collectins. ${ }^{14,100,103}$ An important spatial relationship between the neck and the CRDs is maintained by coordinated interactions between glutamate and lysine residues. ${ }^{104}$ This relationship suggested the possibility of immune cell surface receptor binding in the presence of bound, extended natural $\boldsymbol{L P S}$ and phospholipid ligands. The neck region between the CRD and collagen domain is also responsible for the assembly of the 3 identical polypeptide chains to form the characteristic collectin homotrimers.

In the collagen region, an amino terminal disulfide-rich domain of 7 and 25 amino acids in SP-A (Fig 3,B) and in SP-D (Fig 3,C), respectively, contributes to interchain covalent interactions that stabilize the basic trimeric organization of the collagenlike domains. The second domain contains the collagenlike sequence and forms an extended fibrillar triple helix that is $20 \mathrm{~nm}$ long in SP-A and $46 \mathrm{~nm}$ long in SP-D. ${ }^{99} \mathrm{MBL}$ and SP-A have a single interruption in the Gly-X-Y tripeptide repeat pattern leading to a kink in the fibrillar domain (Fig 3,B), whereas SP-D and conglutinin have uninterrupted repeats throughout the fibrillar domain. SP-D has the most extended collagen domain, which allows it to form an interlinked network with bound inhaled particles. ${ }^{105}$ Conglutinin and SP-D have a characteristic cruciform structure, assembled as tetramers of 3 identical polypeptides (Fig 3, C). The wild-type form of both of these molecules presented a much higher agglutination 
activity than their truncated form that lacked the collagen domain. ${ }^{106,107}$ SP-A and MBL have much smaller collagen domains, with a configuration resembling a bouquet of tulips (Fig 3, B). ${ }^{105}$ These collectins are less efficient to aggregate pathogens than SP-D. ${ }^{108,109}$ Chimeric collectins using the N-terminal collagen domains of SP-D coupled to the neck and CRD of MBL aggregated bacteria more strongly than wildtype MBL, ${ }^{110}$ emphasizing the importance of long collagen stalks. SP-D trimers without the collagen region aggregated pathogens to a smaller degree than the full-length molecule, ${ }^{106}$ and a single-arm SP-D mutant was not able to aggregate pollen starch granules (whereas the wild-type, fully assembled molecule did), suggesting that multimerization of SP-D is also required for proper collectin function. ${ }^{111}$ Indeed, trimeric SP-D could not aggregate bacteria, ${ }^{12-114}$ whereas there was a several-fold greater agglutination activity by a multimer cluster of dodecamer SP-D than by single dodecamers. ${ }^{115,116}$ SP-D can naturally form multimers, socalled "fuzzy balls" with a total mass of several million kilodaltons and a size of about 100 nm. ${ }^{117}$

\section{Carbohydrate specific binding: now collectins distinguish between self and nonself}

A large body of evidence suggests that CRD-dependent attachment is important between collectins and inhaled particles (see review ${ }^{97}$ ) and that there is an essential role for the collagenlike domain and the degree of oligomerization for pathogen aggregation and subsequent phagocytosis. ${ }^{118}$

To recognize a wide variety of pathogen surfaces, collectins should have a broad specificity that is achieved by a very open binding pocket in the CRD. Collectin pattern recognition entails the ability to bind LPS, lipoteichoic acid, and mannan over the less suitable terminal monosaccharides and macropatterns of mammalian glycoconjugates. Distinguishing between self and nonself can also be achieved through recognition of a specific orientation of hydroxyl groups of hexoses predominantly found in mannose, fucose, and N-acetyl-Dglucosamine and glucose, ${ }^{119}$ which are often located in repeating structures on the surface of microbes as a result of glycosylation enzymes that differ from higher organisms. Further, organization of the individual low-affinity sugar-binding sites into trimeric arrays in the collectin CRD allows multivalent ligands to have a matching ligand topology (bridging a distance of 45-53A), which is important to achieve high-affinity binding. ${ }^{13,27,42}$

In addition to common carbohydrate binding activities, collectins have a relative monosaccharide preference. ${ }^{120}$ For instance, although both SP-A and SP-D could recognize the carbohydrate structure of Aspergillus fumigatus, ${ }^{121-123}$ the interaction with SP-A was inhibited with mannose, but with SP-D it was blocked with maltose. ${ }^{124}$ As assessed by saccharide competition in solid phase-binding assays using adsorbed mannan as the ligand, ${ }^{125}$ the order of carbohydrate preference for SP-A was established as Nacetylmannosamine $>$ L-fucose $>$ maltose $>$ glucose $>$ mannose (no inhibition by galactose, $\mathrm{N}$-acetylglucosamine, and $\mathrm{N}$-acetylgalactosamine). The order of preference of human SP-D in solid-phase competition assays using maltosyl-BSA as the ligand was approximately maltose (inositol) > glucose, mannose, fucose > galactose, lactose, glucosamine $>\mathrm{N}$ acetylglucosamine (see review ${ }^{126}$ ). Saccharide specificity may be determined by the trimeric 
neck + CRD domains, given that bacterially expressed trimeric CRDs show the same saccharide inhibition profile as natural human SP-D. ${ }^{127}$

\section{Binding to lipids}

Interactions with surfactant lipids are required to orient the CRDs optimally in relation to the air/lipid or lipid/hypophase (the aqueous lining of the pulmonary epithelium) interface to facilitate uptake of foreign materials embedded in the surfactant layer of the proximal and distal air spaces. Exposed hydrophobic sites could also mediate interactions with hydrophobic domains displayed on various microorganisms, and perhaps stabilize relatively weak lectin-dependent interactions. ${ }^{126}$ Purified SP-A binds to specific surfactant-associated phospholipids, primarily dipalmitoylphosphatidylcholine (DPPC) and galactosylceramide in vitro. ${ }^{128}$ SP-A aggregates surfactant phospholipids in the presence of calcium ${ }^{96,129,130}$ and regulates the uptake and secretion of surfactant lipids by alveolar type II cells in vitro. DPPC binding depends on the collagenase-resistant neck-CRD region, whereas phospholipid aggregation requires oligomerization of SP-A trimers. ${ }^{131}$ This function is important for conversion of surfactant secreted from type II cells in lamellar bodies into the latticelike tubular myelin structure. During surface film construction, the tubular myelin is disaggregated and disassembled, followed by a process of vesicle formation dependent on ventilation of the air-filled lung. Lungs of SP-A deficient mice were shown to have markedly decreased tubular myelin formation, emphasizing the significance of this collectin in proper organization of pulmonary surfactant. ${ }^{132,133}$

SP-A also binds to several glycolipids and neutral glycosphingolipids involving recognition of both the ceramide and saccharide moieties. It is possible that this binding activity can compete for microbial binding to glycolipid receptors recognized by various bacteria and viruses or bacterial toxins. ${ }^{42,126}$

The major surfactant-associated ligand of SP-D is phosphatidylinositol, but it also binds to glucosylceramide. The physiological significance of this binding is supported by a compelling demonstration that SP-D ${ }^{-/}$mice have striking pathological alterations in the lung, including increased surfactant DPPC pool size and abnormalities in type II cells, alveolar macrophages, pulmonary-associated lymphoid tissue, and lung structure. ${ }^{30,42}$ Because it is unlikely that SP-D has a primary role in normal surfactant metabolism, these changes could be secondary to an enhanced inflammatory state of the SP-D ${ }^{-/-}$lung.

\section{Binding to nucleic acids and removal of apoptotic cells}

Lung collectins also bind nucleic acids from a variety of origins, including components of disrupted cells (cell debris) and liberated and cell-surface DNA, thereby contributing to general clearance activities. Binding occurs through both the CRDs and the collagenlike regions. SP-D effectively binds and aggregates alveolar macrophage DNA, and it enhances the uptake of DNA by human monocytic cells. Binding of the collectins to cell-surface DNA might be 1 mechanism by which collectins mediate enhanced phagocytosis of apoptotic cells. Indeed, SP-A and SP-D are both capable of recognizing and binding to apoptotic cells and facilitate their removal by macrophages. ${ }^{134-138}$ Collectins may recognize damaged cells via their $\mathrm{CRD}^{139}$ or collagen region ${ }^{135}$ or independently from those. ${ }^{140}$ Several receptors 
were proposed as candidates to mediate this function; however, the calreticulin/CD91 complex appears to be the most accepted. ${ }^{137}$ The role of the collagen domain-mediated calreticulin/CD91 binding, however, was contradicted by an in vivo study in which treatment with a C-terminal mutant SP-D molecule (that does not contain the collagen domain) restored the macrophage defect and reduced the number of apoptotic cells in the lung of SP-D ${ }^{-/-}$mice. $^{48}$

\section{Role of lung collectins in pathogen uptake}

The consequence of pathogen binding and aggregation by lung collectins is a more efficient phagocytic elimination. Collectin-enhanced particle and pathogen uptake by phagocytes may occur through at least 3 different mechanisms: by regulating cell-surface pattern recognition receptor expression, by opsonizing pathogens, and by functioning as activation ligands. ${ }^{26}$

Pattern recognition receptors play a major part in host defense and regulate tissue homeostasis within multicellular hosts. ${ }^{141}$ Interactions between collectins and these receptors may be significant during both infectious and allergen-induced challenges in the lung. Beharka et $\mathrm{a}^{142}$ showed, for instance, that SP-A selectively enhanced mannose receptor expression on human monocyte- derived macrophages, a process that involved both the attached sugars and the collagenlike domain of SP-A. In contrast, alveolar macrophages from SP-A ${ }^{-/-}$mice had reduced mannose receptor expression compared with wild-type mice. ${ }^{142}$ Such positive regulatory action between collectins and pattern recognition receptors was further suggested in another study, using a model of allergic sensitization. Lack of SP-D in gene-deficient mice resulted in a failure to increase Toll-like receptor (TLR) 4 expression during allergic inflammation in comparison with wild-type mice. $^{143}$

\section{Phagocytosis of bacteria, viruses, and fungi}

Collectin-enhanced phagocytosis was demonstrated for a number of bacteria. Aggregation before uptake was important for Escherichia coli, ${ }^{17}$ Streptococcus pneumoniae, Staphylococcus aureus, ${ }^{112}$ and Cryptococcus neoformans. ${ }^{108}$ Phagocytosis through direct SP-D binding was shown for Pseudomonas aeruginosa, ${ }^{144}$ Haemophilus influenzae, ${ }^{36}$ and the unencapsulated variants of Klebsiella pneumoniae. ${ }^{145}$ On the other hand, SP-A binding significantly enhanced phagocytosis of Mycobacterium tuberculosis and Mycobacterium bovis BCG by alveolar macrophages. ${ }^{146,147}$ Critical evidence for the significance of collectin-mediated phagocytosis of bacteria was provided by numerous studies on genetargeted mice. ${ }^{39}$ These animals were highly susceptible to infection with group B Streptoccus, ${ }^{148,149}$ H influenzae, ${ }^{36}$ and $P$ aeruginosa infections. ${ }^{150}$

Both lung collectins are also involved in neutralization and clearance of inhaled endotoxin. ${ }^{151}$ Gram-negative LPS polysaccharide side chains are known as O-antigens. Full length O-chains would render the LPS smooth, whereas the absence or reduction of Ochains would make the LPS rough. SP-D prefers rough LPS to the smooth LPS, ${ }^{152}$ and unlike SP-A, SP-D does not recognize lipid A as a ligand. ${ }^{153}$ In addition, the LPS component of the pathogens has been identified as a major ligand for SP-D on $E$ coli, ${ }^{17} \mathrm{~K}$ 
pneumoniae, and $P$ aeruginosa. ${ }^{127}$ The binding occurs via the CRD and accordingly is calcium-dependent.

Defense against different strains of influenza A virus involves agglutination mediated through sialic acid residues on the SP-A CRD, ${ }^{154,155}$ or viral hemagglutinin and neuraminidase envelop glycoprotein binding by SP-D. ${ }^{156}$ The collectins, especially SP-D, are potent inhibitors of influenza virus-hemagglutinin - mediated red blood cell agglutination. ${ }^{157}$ Accordingly, SP-D gene-targeted mice show increased susceptibility to influenza A virus infection. ${ }^{38}$ Lung collectins also bind to respiratory syncytial virus (RSV) through the F (fusion; SP-A) and G (attachment; SP-D) glycoproteins in a calciumdependent fashion and inhibit viral infectivity in vitro and in vivo. ${ }^{158,159}$

Fungal pathogens frequently gain access to the host via the respiratory tract. Under normal conditions, fungal infections of the lung are very rare, although fungi like $C$ neoformans and A fumigatus are commonly found in the environment and are continuously inhaled. This suggests that efficient defense mechanisms must exist to protect against these pathogens. The acidic capsule of the fungi is the most important in their pathogenesis because it inhibits phagocytosis and is poorly immunogenic, so it enables the infectious agents to persist for extended periods in the host. ${ }^{160,161}$ Mannan and $\beta(1-6)$ linked glucan represent the major ligands for collectins on the cell walls of fungal pathogens. Although SP-A can bind to both of the aforementioned organisms, it stimulates the phagocytosis of A fumigatus ${ }^{108,124}$ but not $C$ neoformans. ${ }^{162}$ Interestingly, SP-A inhibits phagocytosis of Candida albicans ${ }^{163}$ and Pneumocystis carinii, ${ }^{164}$ and yet SP-A ${ }^{-/-}$mice showed a heightened susceptibility to $P$ carinii pneumonia. ${ }^{165}$ Both rat and human SP-D can bind to $P$ carinii via its $\mathrm{CRD}^{166}$ and mediate its aggregation in vitro. ${ }^{167}$ Unlike SP-A, SP-D enhances agglutination of unencapsulated $C$ neoformans. ${ }^{108}$

The clinical importance of these observations is illustrated by the fact that a heightened susceptibility of children with cystic fibrosis to a range of infectious and allergenic pathogens is linked with extremely low levels of SP-A and SP-D in the bronchoalveolar lavage (BAL) fluid. ${ }^{168}$

\section{Allergen clearance}

Depending on the host's immunologic and genetic status, a range of A fumigatus-associated respiratory diseases have been recognized, the most common of which is allergic bronchopulmonary aspergillosis (ABPA). When the lung of an immunocompromised subject is exposed to A fumigatus, a systemic infection, invasive aspergillosis ensues. In an immunocompetent subject, however, it often results in IgE mediated-asthma. A number of studies using murine models of ABPA or allergic airway sensitization have emphasized the importance of lung collectins in protection against $A$ fumigatus-induced pathologies. ${ }^{75,169-173}$ Treatment with recombinant collectins not only protected against mortality but also inhibited the immunoglobulin, eosinophil, and TH2 cytokine responses in murine models. Interestingly, in patients with ABPA, polymorphisms in the collagen region of SPA2 were associated with increased levels of total IgE antibodies and eosinophilia. ${ }^{174}$ 
An important functional consequence of carbohydrate recognition is the ability of collectins to bind inhaled allergenic material. SP-A readily associates with water-extractable particles of pollen grains, including pollen from Populus nigra italica (Lombardy poplar), Poa pratensis (Kentucky blue grass), Secale cereale (cultivated rye), and Ambrosia elatior (short ragweed). ${ }^{175}$ Further, pollen starch granules extracted from Dactylis glomerata (cocksfoot grass) were aggregated by the CRD of SP-D, ${ }^{111,176}$ and this interaction inhibited the release of $\beta$-hexosaminidase by peritoneal mast cells. Similarly, both SP-D and SP-A were shown to bind to whole mite extracts (Dermatophagoides pteronyssinus) and the purified allergen Der $p 1$ in a carbohydrate-specific and calcium-dependent manner. ${ }^{177,178}$ Lung collectins also inhibited mite extract-specific IgE binding and histamine release in vitro, ${ }^{179}$ indicating a protective importance of calcium and sugar-dependent allergen binding by collectins. ${ }^{180}$

\section{MODULATION OF INNATE AND ADAPTIVE IMMUNITY}

\section{Binding to cell surface receptors}

The first indications of collectin binding to immune cells came from studies investigating the $\mathrm{C} 1 \mathrm{q}$ receptor function on alveolar macrophages. ${ }^{9}$ However, the details of cell function modulation by SP-A and SP-D are still not well understood. Because these proteins are sticky and strongly bind carbohydrate, lipid, and protein ligands, promiscuous binding partners and several putative receptors have been identified (Table I).

The amino terminal collagen tail of the collectins may serve as a ligand for collectin receptors. ${ }^{175,181}$ SP-A, SP-D, MBL, and collectinlike C1q were reported to enhance pathogen phagocytosis and removal of apoptotic cells by binding to $\mathrm{C} 1 \mathrm{q}$ receptor. This receptor (originally termed $\mathrm{cC} 1 \mathrm{qR}$ ), was later shown to recognize all the collectin tails and to be identical to calreticulin. Because the endoplasmic reticulum (ER) membrane fuses with the plasma membrane during phagocytosis, calreticulin (which is a cytoplasmic molecule with an ER retention sequence) is expressed on the cell surface during this process. Calreticulin does not have a transmembrane domain but appears to mediate signaling through the low density lipoprotein-receptor related protein, CD91, ${ }^{12}$ which is found on macrophages. ${ }^{27,182,183}$ Because calreticulin, CD91, SP-A, and SP-D can all bind multiple ligands in a promiscuous manner, the importance and specificity of this receptor-ligand mechanism needs further investigations. Although the calreticulin/CD91 complex explains some of the biological actions mediated by SP-A and SP-D, it is still unclear whether ER recruitment and calreticulin binding is necessary and/or sufficient for phagocytosis. ${ }^{12,137,181,184,185}$

Not only the collagenous tail can act as a ligand for collectin receptors. SP-A for, instance has another receptor on alveolar macrophages called SP receptor 210 (SP-R210, named for its 210-kd size), to which it binds via its globular head. SP-R210 binding mediated ingestion of SP-A-BCG complexes and the ensuing release of TNF- $\alpha$ and nitric oxide and mycobacterial killing by alveolar macrophages and monocytes. ${ }^{147,186,187}$

A 340-kd glycoprotein (gp-340) was originally identified as a pulmonary SP-D binding protein, ${ }^{188}$ but later it was shown to bind SP-A also ${ }^{189}$ in the presence of calcium but independently of the CRD region. This protein has both a soluble and a membrane- 
associated form and functions as an opsonin receptor for various pathogens. ${ }^{190-192}$ Its presence on the membrane surface was not necessary to mediate collectin function (chemotaxis) on macrophages. ${ }^{189}$

Carbohydrate recognition domain-specific interactions with lung cells may be mediated through a number of receptors. Apart from pathogen binding, the CRD region has been involved in modulating functions of various cell types of the immune system. The ability to exert chemotactic activity on neutrophils and monocytes, for instance, was suggested to depend on its lectin activity. ${ }^{193}$ The importance of CRD in immunomodulation was corroborated by studies that used calcium chelation or treatment with sugars that inhibited SP-D-mediated neutrophil phagocytosis ${ }^{112}$ as well as lymphocyte immunosuppression. ${ }^{179}$

Through CRD, SP-A and SP-D can recognize, bind, and modulate function of $\boldsymbol{C D 1 4},{ }^{194,195}$ TLR-2, ${ }^{196,197}$ and TLR-4. ${ }^{197,198}$ Murakami et al ${ }^{196}$ showed that peptidoglycan-induced TNF-a secretion by U937 cells and rat alveolar macrophages was inhibited by SP-A in a dose-dependent manner. Peptidoglycan, which is not a ligand for SP-A, attenuated this inhibitory effect, while SP-A inhibited peptidoglycan binding to soluble TLR-2, indicating a direct interaction. Using macrophages from $\mathrm{C} 3 \mathrm{H} / \mathrm{HeJ}$ mice, which carry an inactivating mutation in the TLR-4 gene, and TLR-4-transfected Chinese hamster ovary cells, Guillot et al ${ }^{198}$ showed that SP-A-induced activation of the NF- $\kappa$ B signaling pathway and upregulation of TNF-a and $\boldsymbol{I L}-\mathbf{1 0}$ were critically dependent on the TLR-4 functional complex. SP-D was also shown to bind both TLR-2 and TLR-4 in a concentrationdependent and calcium-dependent manner. Epitope mapping with recombinant proteins consisting of the CRD and the neck domain plus CRD indicated that human SP-D binds the extracellular domains of TLR-2 and TLR-4 through its CRD by a mechanism different from its binding to phosphatidylinositol and LPS. ${ }^{197}$

Gardai et al ${ }^{185}$ provided in vitro as well as in vivo evidence that SP-A and SP-D (but not MBL or C1q) binding to signal inhibitory regulatory protein (SIRP-a) on macrophages through their globular head inhibits LPS-stimulated and H2O2-stimulated cytokine production ${ }^{185}$ as well as phagocytosis. ${ }^{199}$ Their results confirmed previous studies in which SP-A inhibited $C$ albicans-induced cytokine production by macrophages ${ }^{200}$ that was not reproduced by $\mathrm{Clq}$ and type IV collagen and was independent of Candida-SP-A binding and phagocyte C1q receptor occupancy. These data suggest that inhibition occurs by direct binding to the cell through the globular head of SP-A.

\section{Importance of a dual biological activity}

Gardai et al ${ }^{185}$ further showed that collectin binding to pathogens via CRD and presenting their collagen tail to calreticulin/CD91 on macrophages induced proinflammatory cytokine release and put forward the elegant "head or tail hypothesis" (Fig 4) that lung collectins are capable of differential binding through either their CRD or their collagen domain to cell membrane receptors and eliciting respective anti-inflammatory or proinflammatory signaling pathways. Early indications of dual collectin activity on macrophages came from studies on SP-A and mycobacterial infections: SP-A enhanced phagocytosis of $M$ tuberculosis and $M$ bovis BCG by alveolar macrophages ${ }^{146,147}$ and augmented production of IL-6 in the presence of infection. In the absence of infection, however, SP-A inhibited 
IL-6. ${ }^{201}$ These studies suggested that the nature of collectin-mediated immune functions may depend on whether an immune intervention is needed after infection or allergen exposure or whether an immunosuppressive/anti-inflammatory action would be necessary to prevent chronic tissue damage during inflammatory changes.

According to the "head or tail hypothesis," SP-A and SP-D interacting with pathogens via their globular head, and presenting their collagenous tail to phagocytes to calreticulin/CD91, induce phagocytosis and a proinflammatory response. ${ }^{185}$ In subsequent studies, the Gardai group demonstrated that SP-A or SP-D binding to SIRP-a on residential alveolar macrophages via the CRD suppressed phagocytic function of these cells. ${ }^{199}$ Thus, presence of SP-A and SP-D is necessary for pulmonary immune homeostasis and an immune inhibitory effect on these cells can be mediated through SIRP-a binding and Src homology phosphatase-1 signaling. ${ }^{199}$

\section{Collectin regulation of macrophage function}

Unlike the SP-D ${ }^{-/}$mice that show serious signs of constitutive alveolar macrophage activation, ${ }^{30,35,41,202,203}$ under normal conditions, $\mathrm{SP}-\mathrm{A}^{-/-}$mice display no pathological features in the lung. Under proinflammatory circumstances, however, SP-A enhanced production of TNF-a by macrophages incubated with BCG ${ }^{187}$ and by PBMCs and U937 cells in the presence of RSV. ${ }^{204}$ SP-A, on the other hand, downregulated TNF- $\mathrm{a}$ and other proinflammatory cytokines and chemokines by human alveolar macrophages induced by $C$ albicans $^{200}$ as well as LPS. ${ }^{205}$ Inhibition of the LPS effect on TNF-a by SP-A was specific to smooth LPS and was mediated by blocking CD14. ${ }^{206}$ These data indicate that SP-A has potent pathogen specific regulatory effects on macrophage cytokine production.

In a model of allergic sensitization, in vitro culture of alveolar macrophages together with SP-D and allergen resulted in increased production of the immunosuppressive IL-10 as well as $\boldsymbol{I L}$-12, and IFN- $\gamma$ cytokines unfavorable for development of TH2-type changes. ${ }^{207}$ The protective effect of SP-A and SP-D against allergen-induced TH2-type activation was confirmed by direct inhibition of TH2 cytokine release in allergen-stimulated splenic mononuclear cells in vitro. ${ }^{72,75}$

The effects of lung collectins on free radical production are also pathogen-dependent. SP-D was shown to enhance the amount of oxygen radicals produced by alveolar macrophages and neutrophils, 208 and 2 independent studies showed that SP-A stimulated the release of reactive oxygen metabolites. ${ }^{209,210}$ In spite of these reported effects, SP-D knockout mice have increased oxidant production. ${ }^{36,211}$ Further, in a recent study on allergic sensitization in mice, recombinant SP-D significantly inhibited allergen-induced and LPS-induced nitric oxide production by isolated alveolar macrophages. ${ }^{212}$ Interestingly, lung collectins showed additional protective effects because they appeared to be potent endogenous inhibitors of lipid peroxidation and oxidative cellular injury. ${ }^{213}$

Alveolar macrophages need to home to the lung constitutively to perform their immune surveillance function without the presence of inflammation. Lung collectins have significant chemotactic activities on alveolar macrophages. Both SP-A and SP-D stimulated chemotaxis in a concentration-dependent manner ${ }^{214}$ and induced directional actin polymerization in 
alveolar macrophages in vitro. ${ }^{189}$ In this latter study, it was also demonstrated that this effect is cell-specific and collectin-specific, because SP-A did not stimulate the chemotaxis of monocytes ${ }^{215}$ whereas in another study, SP-D attracted these cells. ${ }^{193}$ Binding of collectins to macrophages probably occurred independently from the $\mathrm{C} 1 \mathrm{q}$ receptor, because $\mathrm{C} 1 \mathrm{q}$ did not show the same chemotactic effect on macrophages.

Taken together, these studies indicate that lung collectins recognize many pathogens by using various binding motifs that are frequently, but not always, targets for the collectin CRD. Pathogen sensing then leads to aggregation, phagocytosis, and regulated release of inflammatory mediators (Fig $4, B$ ). The importance of this mechanism is supported by evidence obtained using gene-targeted mice in models of infection and allergic sensitization. In spite of an exaggerated inflammatory response, these animals show impaired clearance of a number of bacteria, viruses, and fungal pathogens. These studies also strongly suggest that direct binding of collectins to phagocytes in the presence and absence of pathogens may result in different (proinflammatory or anti-inflammatory) outcomes (Fig 4, $A$ and B).

\section{Effects of lung collectins on dendritic cells}

An important implication of both phagocytosis and direct binding of collectins to antigen presenting cells is the ensuing regulation of adaptive immune response (Fig 5, $A$ ). Studies investigating the effects of collectins on dendritic cells showed that SP-A inhibited whereas SP-D augmented antigen presentation by bone marrow-derived (myeloid) dendritic cells. ${ }^{216,217}$ SP-D, however, inhibited antigen presentation when dendritic cells were isolated from the lung. ${ }^{218}$ Under baseline conditions, dendritic cells reside in the lung tissue in an immature state. These resting cells are scattered throughout in the bronchial and alveolar wall, capturing inhaled pathogens but unable to present them to T cells. In response to danger signals such as pathogens, proinflammatory cytokines, or necrotic cells, dendritic cells start to mature and switch from an antigen-capturing to an antigen-presenting and Tcell-stimulating proinflammatory state. ${ }^{219}$ Although all mature dendritic cells share a common ability to process and present antigen to naive $\mathrm{T}$ cells for the initiation of an immune response, they differ in origin, migratory patterns, localization, and cytokine production. ${ }^{220}$ Plasmocytoid dendritic cells make up the majority in the lung under baseline conditions, ${ }^{221}$ and these cells were shown to be tolerogenic in allergen-induced inflammation. On the other hand, myeloid dendritic cells migrate rapidly to the lung during a TH2-type inflammation and exert potent TH2-cell activation. ${ }^{222-224}$

Dendritic cells in the BAL of SP-D ${ }^{-/-}$mice had a myeloid (bone marrow-derived) phenotype and constitutive TNF-a expression. In bone marrow-derived dendritic cell cultures, administration of SP-D suppressed both the activation marker and autocrine TNF- $a$ expression. Thus, SP-D can alter the differentiation and inhibit activation of immature dendritic cells through inhibition of TNF-a (Fig 5, A) ${ }^{203}$ Interestingly, dendritic cells in the lung of SP-D ${ }^{-/-}$mice were unable to migrate to the regional lymph nodes and accumulated instead in the airway submucosal tissue (S. Kierstein and A. Haczku, unpublished data, June 2006), possibly because of a markedly increased expression of thymus and activationregulated chemokine (TARC) ${ }^{75}$ Activated myeloid dendritic cells themselves release large amounts TARC, which selectively attracts more activated dendritic cells and TH2 
lymphocytes into the lung, creating a vicious TH2-type inflammatory circle. TNF-a is a potent activator of TARC release. By suppressing TNF-a, SP-D provides an efficient lock on the autocrine TNF-a/TARC proinflammatory pathway.

\section{Effects of lung collectins on the adaptive immune response}

Pulmonary lymphocytes are hyporesponsive to a variety of antigenic stimuli compared with peripheral blood leukocytes. There is also evidence that the alveolar lining fluid contributes to the induction and maintenance of such cellular hyporesponsiveness in vivo and in vitro. ${ }^{225-227}$ These early studies, which suggested a role for the alveolar lining fluid in immune defense, were more recently confirmed by the use of collectin-deficient mice. Investigations of SP-A gene-targeted mice (infected with influenza A virus) showed an increase of $\mathrm{B}$ and activated $\mathrm{T}$ lymphocytes in the lung compared with wild-type mice. ${ }^{228}$ Similarly, there was marked T-cell activation observed in the lungs of SP-D-deficient mice, as reflected by an increased percentage of both CD4+ and CD8+ T cells expressing the activation markers $\boldsymbol{C D 6 9}$ and $\boldsymbol{C D 2 5}$ in the BAL. ${ }^{33,75}$ Binding and sequestering of the inhaled antigens may be 1 way to interfere with T-cell activation. However, because lung collectins were also capable of inhibiting mitogen-induced T cells, ${ }^{72,75}$ blocking of antigenT-cell receptor interaction may not be the major pathway for inhibition of lymphocyte function.

Surfactant protein A inhibited T-cell proliferation and decreased IL-2 production ${ }^{229}$ via its collagenlike domain through SP-R210. ${ }^{230}$ SP-D also inhibited T-cell proliferation ${ }^{231}$ in response to both antigenic and mitogenic activation, ${ }^{232}$ but no receptor has been identified to mediate this function. Further, an IL-2-independent mechanism may be also involved, but viability was not affected. ${ }^{233}$ However, the inhibitory effects of surfactant proteins on PHAstimulated and Der $p$-stimulated lymphocytes were attenuated when cells were derived from children with asthma with acute attacks. ${ }^{179}$ These results indicated that $\mathrm{T}$ cells that are already activated may be resistant to the inhibitory effects of collectins.

In summary, lung collectins directly inhibit $\mathrm{T}$-cell activation stimulated by either mitogens or antigens (Fig 5, B). This effect does not depend on interfering with antigen-T-cell interaction and does not alter viability. In addition to inhibition of T-cell function, SP-A and SP-D can influence neutrophils, monocytes, basophils, and mast cells (see review ${ }^{180}$ ).

The in vivo consequences of collectin interaction with T-cell- dependent inflammatory events were demonstrated in various models of allergic airway sensitization. Treatment of allergen-sensitized mice with recombinant or purified collectins was effective in reducing the eosinophilic inflammation and specific IgE production. ${ }^{169-172,212,234}$ Furthermore, airway hyperresponsiveness was also inhibited, and there was a shift from a $\mathrm{T}_{\mathrm{H}} 2$ cytokine pattern toward a $\mathrm{T}_{\mathrm{H}} 1$ response ex vivo ${ }^{169,170}$ and in vitro. ${ }^{75,207}$ SP-A and SP-D-deficient mice exhibited intrinsic hypereosinophilia, ${ }^{50}$ increased IL-13, ${ }^{50,75,143}$ and TARC ${ }^{75,235}$ levels in the BAL, indicating a diminished control of inflammation in these animals. 


\section{CLINICAL SIGNIFICANCE}

\section{Lung collectin gene polymorphisms in bacterial sensing and disease susceptibility}

The association of qualitative and quantitative differences in gene expression and their correlations with airway disease have been extensively studied, and polymorphic lung collectin alleles were identified and associated with susceptibility to a number of diseases $^{236-239}$ (Table II).

The human SP-A locus has 2 functional genes, SP-A1 and SP-A2 in opposite transcriptional orientation, and a nonfunctional gene 240,241 in addition to sequence variability within the $3^{\prime}$ untranslated region. ${ }^{77,242,243}$ Although SP-A1 and SP-A2 are both detected in the human BAL and have a $96 \%$ protein sequence identity, SP-A2 is more effective in stimulating phagocytosis, ${ }^{244,245}$ binding carbohydrates, ${ }^{246}$ inhibiting surfactant secretion, ${ }^{247}$ and inducing TNF-a release by macrophagelike THP- 1 cells. ${ }^{248,249}$

Using coding sequence differences, a number of SP-A1 and SPA2 alleles have been identified as frequent $(>1 \%)$ in the general population. ${ }^{250,251}$ Amino acid changes occur in the mature secreted SP-A1 alleles at positions 19, 50, and 219, and in the SP-A2 alleles at amino acids 9, 91, and 223. The major SP-A1/SP-A2 haplotype (1A0/6A2) represents 55\% to $57 \%$ of all SPA alleles, was shown to result in reduced SP-A mRNA expression, ${ }^{252}$ and is associated with various respiratory illnesses in independent populations. ${ }^{63,253}$ The main SP-A haplotype, interactively with the SP-B Ile131Thr polymorphism, also influences the risk of respiratory distress syndrome and may be also important in susceptibility to influenza virus. ${ }^{254}$

Respiratory syncytial virus can directly alter SP-A gene and protein expression in type II alveolar epithelial cells ${ }^{255}$; therefore, it is important that the SP-A2 Gln223Lys allele (1A1) is overrepresented whereas the SP-A2 Ala91Pro allele is underrepresented in infants with severe RSV infections. ${ }^{256}$ These mutations affect SP-A binding to RSV (the Gln223Lys mutation is in the CRD of the molecule) as well as the function of the collagenous region (which contains the SP-A2 Ala91Pro), resulting in an impaired host defense capability. The SP-A2 1A1 allele also increases susceptibility to Neisseria meningitidis, ${ }^{257}$ supporting the importance of CRD. Mutations in SP-A2 in addition may play a role in susceptibility to Aspergillus-mediated allergies ${ }^{174}$ and $M$ tuberculosis infection, ${ }^{258}$ whereas the SP-A1 6A4 allele was found with higher frequency in idiopathic pulmonary fibrosis. ${ }^{259}$

Four polymorphisms have been identified within the SP-D gene, including the nonsynonymous Met11Thr, Ala160Thr, Ser270Thr, and a synonymous Ala286Ala mutation. The Met11Thr and Ala160Thr polymorphisms in the amino terminal and collagen domain have a frequency exceeding 20\%, whereas the Ser270Thr and Ala286Ala polymorphisms are relatively rare. To date, only the polymorphism in amino acid 11 has been associated with disease. ${ }^{250,260}$ Importantly, individuals with the Met11Thr-encoding genotype had significantly lower SP-D serum levels than individuals with the Met11Met genotype. ${ }^{261}$ The Met11Thr allele is linked with protection from severe RSV infection in infants, whereas the Met11Met allele is associated with RSV bronchiolitis, and the Thr11coding allele is associated with susceptibility to $M$ tuberculosis infection. ${ }^{260,262}$ Studies 
have suggested that the Met11Met allele produces SP-D of both low-molecular-weight and high-molecular-weight forms (monomers, trimers, and dodecamers), whereas the Thr11 produces mainly low-molecular-weight structures (monomers). ${ }^{261}$ It was also shown that the high-molecular-weight form of SP-D has an increased binding affinity to complex microorganisms, whereas low-molecular weight SP-D preferentially bound LPS. Further, in a recent study, significantly more atopic black children had the Met allele compared with nonatopic black children, indicating differential regulation of allergic sensitization. ${ }^{235}$ It appears therefore that the different alleles of codon 11 can influence SP-D oligomerization, which can result in markedly different SP-D serum levels and function. ${ }^{261}$

Nucleotide polymorphisms that do not result in amino acid changes were also identified in the lung collectin genes. These are called silent or, if exons are involved, synonymous mutations and generally thought to be evolutionarily neutral because these polymorphisms do not alter protein function. However, because of possible codon usage biases,

translational stability, splicing, or transcriptional control of expression of the lung collectins may be significantly affected. Indeed, chronic obstructive pulmonary disease susceptibility was associated with such polymorphisms in the SP-A and SP-D genes. ${ }^{263,264}$

\section{SUMMARY}

During the inflammatory airway response, the lung collectins play immune-protective roles in multiple levels. The mechanistic significance of these molecules from the onset to resolution of the inflammatory airway response is illustrated by the fact that lung collectins are capable of differential (proinflammatory or anti-inflammatory) regulation of innate immune cell function. The outcome of collectin-cell interactions may be dictated by binding orientation (either via the CRD or through the collagen region ${ }^{13,185}$ ), receptor signaling (Table I), and the cytokine/inflammatory mediator milieu of the local environment. ${ }^{265}$ The ability to achieve differential effects on the innate immune response by the same molecules carries obvious benefits. On the basis of recent human studies on genetic polymorphisms and chronic inflammatory lung disease, it appears that deficiency in expression and/or function of lung collectins is associated with enhanced susceptibility to infections and inflammation, particularly in severe conditions such as cystic fibrosis 168,266 and chronic obstructive pulmonary disease. ${ }^{267}$ Further studies are needed, however, to understand better the clinical significance of allelic variations in collectin expression and function and to aid future clinical investigations into the use of collectin preparations for therapeutic manipulations of the pulmonary immune system.

\section{Acknowledgments}

Supported by an American Lung Association Career Investigator Award, R01AI055593, and R01HL076646.

We thank Dr Imre Redai (Columbia University) for his help in preparation of this article.

\section{Abbreviations usedGLOSSARY}

ABPA Allergic bronchopulmonary aspergillosis 


\begin{tabular}{ll} 
BAL & Bronchoalveolar lavage \\
C1 & Complement component 1 \\
C1qr & Complement 1q-receptor \\
C/EBP & CCAAT/enhancer-binding protein \\
CL & Collectin \\
CRD & Carbohydrate recognition domain \\
DPPC & Dipalmitoylphosphatidylcholine \\
ER & Endoplasmic reticulum \\
MBL & Mannose-binding lectin \\
NFAT & Nuclear factor of activated T cells \\
NF- $k$ B & Nuclear factor- $\kappa$ B \\
NKT & Natural killer T \\
RSV & Respiratory syncytial virus \\
SIRP & Signal inhibitory regulatory protein \\
SP & Surfactant protein \\
SP-R210 & Surfactant protein receptor 210 \\
STAT & Signal transducers and activators of transcription \\
TARC & Thymus and activation-regulated chemokine \\
TLR & Toll-like receptor \\
TTF & Thyroid transcription factor \\
\hline
\end{tabular}
ADIPONECTIN
Adiponectin decreases $\mathrm{T}_{\mathrm{H}} 2$ inflammation in mouse models of asthma and decreases insulin resistance in mouse models of diabetes. Treatment with adiponectin increases IL-10 production from macrophages. Pulmonary tissue expresses 3 adiponectin receptors (T-cadherin, AdipoR1, R2).
C1q
The first component of the classic complement cascade, $\mathrm{C} 1$ is composed of a trimeric complex of $\mathrm{C} 1 \mathrm{q}, \mathrm{r}$, and s. C1q is the $\mathrm{C} 1$ subunit that binds aggregated immunoglobulin, resulting in the activation of $\mathrm{C} 1 \mathrm{r}$ (a serine protease). Free C1q binds the C1q receptor, which increases phagocytic capacity of neutrophils and macrophages. C1q deficiency, inherited in an autosomal-recessive pattern, is 
CD69, CD25

\section{CODON USAGE BIAS, TRANSLATIONAL STABILITY, TRANSCRIPTIONAL CONTROL, SYNONYMOUS/ NONSYNONYMOUS MUTATIONS}

\section{EXON DUPLICATION AND SHUFFLING}

\section{GALACTOSYLCERAMIDE}

associated with a lupus-like rash, fever, arthritis, and glomerulonephritis.

CD69 is a marker of activated T lymphocytes, B cells, eosinophils, neutrophils, and platelets. CD25 is the achain of the IL-2 receptor and is found on activated T cells as well as regulatory $\mathrm{T}$ cells, eosinophils, and B cells.

Codon usage bias refers to the differences in the frequency of usage for a certain base triplet for a given amino acid among organisms. This phenomenon can play a role in molecular evolution because codon usage bias will influence the available tRNA pool and thus the translational efficiency of any given nucleotide triplet for the same amino acid, theoretically making some proteins more efficiently translated than others. Translational stability refers to the stability of the mRNA before its translation into protein, whereas transcriptional control occurs via promoter and enhancer sequences to alter the rate of gene transcription. Codon usage bias, translational stability, and transcriptional control all serve as mechanisms for ultimately affecting protein levels. Synonymous mutations are base pair changes in an exon that do not change the amino acid code in the protein. Nonsynonymous mutations are base pair changes that alter an existing amino acid codon, resulting in a change in the protein sequence.

Mechanisms for genomic diversity and evolution include exon duplication and shuffling. The theory of exon shuffling explains the assembly/formation of new genes that can occur by the assembly of exon fragments, made possible because of the genomic organization of alternating exons and introns (coding and noncoding regions) and alternate splicing with recombination. Exon duplication can be considered one form of exon shuffling.

A glycolipid antigen that is presented by CD1d to invariant natural killer T (NKT) cells. NKT cells are detected using tetramers loaded with $\mathrm{a}$ galactosylceramide. Presentation of agalactosylceramide to NKT cells leads to the 
IL-10, IL-12, IFN- $\gamma$

LPS

MANNOSE-BINDING LECTIN (MBL)

\section{NEGATIVE \\ GLUCOCORTICOID RESPONSE ELEMENT}

\author{
SIGNAL TRANSDUCERS \\ AND ACTIVATORS OF \\ TRANSCRIPTION (STAT), \\ AP-1, NUCLEAR FACTOR \\ OF ACTIVATED T CELLS \\ (NFAT)
}

production of IL-12 by antigen-presenting cells and of IL-4, IL-13, IL-10, and TGF- $\beta$ by NKT cells.

IL-10, IL-12, and IFN- $\gamma$ are all cytokines that dampen the $\mathrm{T}_{\mathrm{H}} 2$ response. IL-12 is a dimer of $\mathrm{p} 40 / 35$ that induces IFN- $\gamma$ production and a shift to $\mathrm{T}_{\mathrm{H}} 1$ phenotype. IL-12p40 and IL-12 receptor deficiency leads to severe nontuberculous mycobacterial infections. IL-10 is produced by regulatory $\mathrm{T}$ cells and increases in therapies that reduce inflammation, such as specific immunotherapy. IL-10-deficient mice develop spontaneous colitis similar to human Crohn disease.

LPS is a component of the outer membrane of gramnegative bacteria. Smooth LPS has O-polysaccharides, whereas rough LPS lacks O-polysaccharides. Smooth strains of bacteria are more virulent, elicit an antibody response, and are more resistant to clearance.

The lectin pathway for complement activation uses MBL binding to mannans on bacterial surface resulting in activation of the MBL associated serine proteases 1 and 2, analogous to activated C1. MBL binds a number of monosaccharides including mannose, $\mathrm{N}$-acetylglucosamine, and L-fucose. MBL associated serine proteases cleave $\mathrm{C} 4$ and $\mathrm{C} 2$ with subsequent cleavage of $\mathrm{C} 3$ and activation of the terminal complement cascade. MBL deficiency may be related to increased infectious susceptibility, including in the respiratory tract.

Glucocorticoid receptors are nuclear steroid receptors that dimerize and bind to the glucocorticoid response elements to activate or repress transcription.

Decreased gene transcription can occur when glucocorticoid receptors bind to a negative glucocorticoid response element consensus sequence (ATYACnnTnTGATCn).

AP-1: Heteromeric complexes of jun and fos that activate transcription of the IL-2, IL-4, IL-5, TNF, and GM-CSF promoters. NFAT: A Rel transcription family member. Calcineurin-induced dephosphorylation of NFAT is required for nuclear localization. NFAT is modulated by cyclosporine and tacrolimus, which both bind to immunophilins and 


\section{THYMUS AND \\ ACTIVATION-REGULATED CHEMOKINE (TARC)}

\author{
TOLL-LIKE RECEPTOR \\ (TLR)-4, CD14
}

block the phosphotase activity of calcineurin. STAT: STAT act as phosphorylated dimers that bind to palindromic DNA elements in response to Janusactivated kinase pathways. STAT1, STAT2, STAT3, STAT4, STAT5, and STAT6 are downstream of IFN, IL-2, IL-6, IL-10, IL-12, IL-2, and IL-4, IL-13 signaling.

Also known as chemokine ligand 17 (CCL17), TARC binds to the chemokine receptor 4 (CCR4), which is increased on $\mathrm{T}_{\mathrm{H}} 2$ cells and activated dendritic cells, promoting trafficking to sites of inflammation in asthma and atopic dermatitis.

TLRs are transmembrane receptors in the innate immune system that activate antigen-presenting cells. TLR ligands are microorganism/pathogen associated molecular patterns. TLR-2 binds to lipotechoic acid on gram-positive bacteria; TLR-4 binds lipotechoic acid as well as LPS on gram-negative bacteria. Endogenous ligands for TLR-4 include fibronectin and $\beta$ defensin-2. TLR-4 uses CD14 to activate the nuclear factor- $\kappa \mathrm{B}(\mathrm{NF}-\kappa \mathrm{B})$ pathway and production of IL-6, IL-12, and TNF-a. Mutations of TLR-mediated immunity can result in primary immunodeficiency made up of recurrent pyogenic infections with poor polysaccharide antibody response (IL-1 receptorassociated kinase 4 [IRAK-4]) and herpes simplex virus encephalitis (TLR-3).

\section{REFERENCES}

1. Klaus MH, Clements JA, Havel RJ. Composition of surface-active material isolated from beef lung. Proc Natl Acad Sci U S A. 1961; 47:1858-1859. [PubMed: 14456669]

2. Clements JA. Surfactant in pulmonary disease. N Engl J Med. 1965; 272:1336-1337. [PubMed: 14299144]

3. King RJ, Klass DJ, Gikas EG, Clements JA. Isolation of apoproteins from canine surface active material. Am J Physiol. 1973; 224:788-795. [PubMed: 4633419]

4. White RT, Damm D, Miller J, Spratt K, Schilling J, Hawgood S, et al. Isolation and characterization of the human pulmonary surfactant apoprotein gene. Nature. 1985; 317:361-363. [PubMed: 2995821]

5. Benson B, Hawgood S, Schilling J, Clements J, Damm D, Cordell B, et al. Structure of canine pulmonary surfactant apoprotein: cDNA and complete amino acid sequence. Proc Natl Acad Sci U S A. 1985; 82:6379-6383. [PubMed: 3863100]

6. Floros J, Steinbrink R, Jacobs K, Phelps D, Kriz R, Recny M, et al. Isolation and characterization of cDNA clones for the 35-kDa pulmonary surfactant-associated protein. J Biol Chem. 1986; 261:9029-9033. [PubMed: 3755136] 
7. Sano K, Fisher J, Mason RJ, Kuroki Y, Schilling J, Benson B, et al. Isolation and sequence of a cDNA clone for the rat pulmonary surfactant-associated protein (PSP-A). Biochem Biophys Res Commun. 1987; 144:367-374. [PubMed: 3579914]

8. Persson A, Rust K, Chang D, Moxley M, Longmore W, Crouch E. CP4: a pneumocyte-derived collagenous surfactant-associated protein: evidence for heterogeneity of collagenous surfactant proteins. Biochemistry. 1988; 27:8576-8584. [PubMed: 3219363]

9. Tenner AJ, Robinson SL, Borchelt J, Wright JR. Human pulmonary surfactant protein (SP-A), a protein structurally homologous to C1q, can enhance FcR- and CR1-mediated phagocytosis. J Biol Chem. 1989; 264:13923-13928. [PubMed: 2788165]

10. Malhotra R, Thiel S, Reid KB, Sim RB. Human leukocyte C1q receptor binds other soluble proteins with collagen domains. J Exp Med. 1990; 172:955-959. [PubMed: 2388038]

11. Stuart GR, Lynch NJ, Day AJ, Schwaeble WJ, Sim RB. The C1q and collectin binding site within C1q receptor (cell surface calreticulin). Immunopharmacology. 1997; 38:73-80. [PubMed: 9476117]

12. Ogden CA, deCathelineau A, Hoffmann PR, Bratton D, Ghebrehiwet B, Fadok VA, et al. C1q and mannose binding lectin engagement of cell surface calreticulin and CD91 initiates macropinocytosis and uptake of apoptotic cells. J Exp Med. 2001; 194:781-795. [PubMed: 11560994]

13. Fraser DA, Tenner AJ. Directing an appropriate immune response: the role of defense collagens and other soluble pattern recognition molecules. Curr Drug Targets. 2008; 9:113-122. [PubMed: 18288962]

14. Drickamer K, McCreary V. Exon structure of a mannose-binding protein gene reflects its evolutionary relationship to the asialoglycoprotein receptor and nonfibrillar collagens. J Biol Chem. 1987; 262:2582-2589. [PubMed: 3029088]

15. Haagsman HP, Hawgood S, Sargeant T, Buckley D, White RT, Drickamer K, et al. The major lung surfactant protein, SP 28-36, is a calcium-dependent, carbohydrate-binding protein. J Biol Chem. 1987; 262:13877-13880. [PubMed: 2820982]

16. Gupta G, Surolia A. Collectins: sentinels of innate immunity. Bioessays. 2007; 29:452-464. [PubMed: 17450595]

17. Kuan SF, Rust K, Crouch E. Interactions of surfactant protein D with bacterial lipopolysaccharides: surfactant protein $\mathrm{D}$ is an Escherichia coli-binding protein in bronchoalveolar lavage. J Clin Invest. 1992; 90:97-106. [PubMed: 1634623]

18. Hansen S, Holmskov U. Lung surfactant protein D (SP-D) and the molecular diverted descendants: conglutinin, CL-43 and CL-46. Immunobiology. 2002; 205:498-517. [PubMed: 12396011]

19. Fujita T. Evolution of the lectin-complement pathway and its role in innate immunity. Nat Rev Immunol. 2002; 2:346-353. [PubMed: 12033740]

20. Holmskov U, Thiel S, Jensenius JC. Collections and ficolins: humoral lectins of the innate immune defense. Annu Rev Immunol. 2003; 21:547-578. [PubMed: 12524383]

21. Runza VL, Schwaeble W, Mannel DN. Ficolins: novel pattern recognition molecules of the innate immune response. Immunobiology. 2008; 213:297-306. [PubMed: 18406375]

22. Lu JH, Thiel S, Wiedemann H, Timpl R, Reid KB. Binding of the pentamer/hexamer forms of mannan-binding protein to zymosan activates the proenzyme $\mathrm{C} 1 \mathrm{r} 2 \mathrm{C} 1 \mathrm{~s} 2$ complex, of the classical pathway of complement, without involvement of C1q. J Immunol. 1990; 144:2287-2294. [PubMed: 2313094]

23. Ji X, Azumi K, Sasaki M, Nonaka M. Ancient origin of the complement lectin pathway revealed by molecular cloning of mannan binding protein-associated serine protease from a urochordate, the Japanese ascidian, Halocynthia roretzi. Proc Natl Acad Sci U S A. 1997; 94:6340-6345. [PubMed: 9177219]

24. Sekine H, Kenjo A, Azumi K, Ohi G, Takahashi M, Kasukawa R, et al. An ancient lectindependent complement system in an ascidian: novel lectin isolated from the plasma of the solitary ascidian, Halocynthia roretzi. J Immunol. 2001; 167:4504-4510. [PubMed: 11591777]

25. Watford WT, Ghio AJ, Wright JR. Complement-mediated host defense in the lung. Am J Physiol Lung Cell Mol Physiol. 2000; 279:L790-L798. [PubMed: 11053012] 
26. Wright JR. Immunoregulatory functions of surfactant proteins. Nat Rev Immunol. 2005; 5:58-68. [PubMed: 15630429]

27. Kishore U, Greenhough TJ, Waters P, Shrive AK, Ghai R, Kamran MF, et al. Surfactant proteins SP-A and SP-D: structure, function and receptors. Mol Immunol. 2006; 43:1293-1315. [PubMed: 16213021]

28. Crouch E, Wright JR. Surfactant proteins a and d and pulmonary host defense. Annu Rev Physiol. 2001; 63:521-554. [PubMed: 11181966]

29. van de Wetering JK, van Golde LM, Batenburg JJ. Collectins: players of the innate immune system. Eur J Biochem. 2004; 271:1229-1249. [PubMed: 15030473]

30. Botas C, Poulain F, Akiyama J, Brown C, Allen L, Goerke J, et al. Altered surfactant homeostasis and alveolar type II cell morphology in mice lacking surfactant protein D. Proc Natl Acad Sci U S A. 1998; 95:11869-11874. [PubMed: 9751757]

31. Elhalwagi BM, Zhang M, Ikegami M, Iwamoto HS, Morris RE, Miller ML, et al. Normal surfactant pool sizes and inhibition-resistant surfactant from mice that overexpress surfactant protein A. Am J Respir Cell Mol Biol. 1999; 21:380-387. [PubMed: 10460755]

32. Fisher JH, Sheftelyevich V, Ho YS, Fligiel S, McCormack FX, Korfhagen TR, et al. Pulmonaryspecific expression of SP-D corrects pulmonary lipid accumulation in SP-D gene-targeted mice. Am J Physiol Lung Cell Mol Physiol. 2000; 278:L365-L373. [PubMed: 10666121]

33. Fisher JH, Larson J, Cool C, Dow SW. Lymphocyte activation in the lungs of SP-D null mice. Am J Respir Cell Mol Biol. 2002; 27:24-33. [PubMed: 12091242]

34. Zhang L, Ikegami M, Dey CR, Korfhagen TR, Whitsett JA. Reversibility of pulmonary abnormalities by conditional replacement of surfactant protein D (SP-D) in vivo. J Biol Chem. 2002; 277:38709-38713. [PubMed: 12163500]

35. Hawgood S, Ochs M, Jung A, Akiyama J, Allen L, Brown C, et al. Sequential targeted deficiency of SP-A and -D leads to progressive alveolar lipoproteinosis and emphysema. Am J Physiol Lung Cell Mol Physiol. 2002; 283:L1002-L1010. [PubMed: 12376353]

36. LeVine AM, Whitsett JA, Gwozdz JA, Richardson TR, Fisher JH, Burhans MS, et al. Distinct effects of surfactant protein A or D deficiency during bacterial infection on the lung. J Immunol. 2000; 165:3934-3940. [PubMed: 11034401]

37. Vaandrager AB, van Golde LM. Lung surfactant proteins A and D in innate immune defense. Biol Neonate. 2000; 77(suppl 1):9-13. [PubMed: 10828580]

38. LeVine AM, Whitsett JA, Hartshorn KL, Crouch EC, Korfhagen TR. Surfactant protein D enhances clearance of influenza A virus from the lung in vivo. J Immunol. 2001; 167:5868-5873. [PubMed: 11698462]

39. LeVine AM, Whitsett JA. Pulmonary collectins and innate host defense of the lung. Microbes Infect. 2001; 3:161-166. [PubMed: 11251302]

40. Ikegami M, Hull WM, Yoshida M, Wert SE, Whitsett JA. SP-D and GM-CSF regulate surfactant homeostasis via distinct mechanisms. Am J Physiol Lung Cell Mol Physiol. 2001; 281:L697L703. [PubMed: 11504698]

41. Hawgood S, Akiyama J, Brown C, Allen L, Li G, Poulain FR. GM-CSF mediates alveolar macrophage proliferation and type II cell hypertrophy in SP-D gene-targeted mice. Am J Physiol Lung Cell Mol Physiol. 2001; 280:L1148-L1156. [PubMed: 11350793]

42. Hawgood S, Poulain FR. The pulmonary collectins and surfactant metabolism. Annu Rev Physiol. 2001; 63:495-519. [PubMed: 11181965]

43. Zhang L, Ikegami M, Crouch EC, Korfhagen TR, Whitsett JA. Activity of pulmonary surfactant protein-D (SP-D) in vivo is dependent on oligomeric structure. J Biol Chem. 2001; 276:1921419219. [PubMed: 11278637]

44. Zhang P, McAlinden A, Li S, Schumacher T, Wang H, Hu S, et al. The amino-terminal heptad repeats of the coiled-coil neck domain of pulmonary surfactant protein $d$ are necessary for the assembly of trimeric subunits and dodecamers. J Biol Chem. 2001; 276:19862-19870. [PubMed: 11279100]

45. Clark H, Palaniyar N, Strong P, Edmondson J, Hawgood S, Reid KB. Surfactant protein D reduces alveolar macrophage apoptosis in vivo. J Immunol. 2002; 169:2892-2899. [PubMed: 12218102] 
46. Zhang L, Hartshorn KL, Crouch EC, Ikegami M, Whitsett JA. Complementation of pulmonary abnormalities in SP-D(-/-) mice with an SP-D/conglutinin fusion protein. J Biol Chem. 2002; 277:22453-22459. [PubMed: 11956209]

47. Li G, Siddiqui J, Hendry M, Akiyama J, Edmondson J, Brown C, et al. Surfactant protein-Adeficient mice display an exaggerated early inflammatory response to a beta-resistant strain of influenza A virus. Am J Respir Cell Mol Biol. 2002; 26:277-282. [PubMed: 11867335]

48. Clark H, Palaniyar N, Hawgood S, Reid KB. A recombinant fragment of human surfactant protein $\mathrm{D}$ reduces alveolar macrophage apoptosis and pro-inflammatory cytokines in mice developing pulmonary emphysema. Ann N Y Acad Sci. 2003; 1010:113-116. [PubMed: 15033705]

49. Collins RA, Ikegami M, Korfhagen TR, Whitsett JA, Sly PD. In vivo measurements of changes in respiratory mechanics with age in mice deficient in surfactant protein D. Pediatr Res. 2003; 53:463-467. [PubMed: 12595595]

50. Madan T, Reid KB, Singh M, Sarma PU, Kishore U. Susceptibility of mice genetically deficient in the surfactant protein (SP)-A or SP-D gene to pulmonary hypersensitivity induced by antigens and allergens of Aspergillus fumigatus. J Immunol. 2005; 174:6943-6954. [PubMed: 15905537]

51. Sullivan LC, Daniels CB, Phillips ID, Orgeig S, Whitsett JA. Conservation of surfactant protein A: evidence for a single origin for vertebrate pulmonary surfactant. J Mol Evol. 1998; 46:131-138. [PubMed: 9452514]

52. Drickamer K, Dodd RB. C-Type lectin-like domains in Caenorhabditis elegans: predictions from the complete genome sequence. Glycobiology. 1999; 9:1357-1369. [PubMed: 10561461]

53. Holmskov UL. Collectins and collectin receptors in innate immunity. APMIS Suppl. 2000; 100:159. [PubMed: 11021254]

54. Lawson PR, Perkins VC, Holmskov U, Reid KB. Genomic organization of the mouse gene for lung surfactant protein D. Am J Respir Cell Mol Biol. 1999; 20:953-963. [PubMed: 10226065]

55. Rust K, Grosso L, Zhang V, Chang D, Persson A, Longmore W, et al. Human surfactant protein D: SP-D contains a C-type lectin carbohydrate recognition domain. Arch Biochem Biophys. 1991; 290:116-126. [PubMed: 1898081]

56. Madsen J, Tornoe I, Nielsen O, Koch C, Steinhilber W, Holmskov U. Expression and localization of lung surfactant protein A in human tissues. Am J Respir Cell Mol Biol. 2003; 29:591-597. [PubMed: 12777246]

57. Paananen R, Sormunen R, Glumoff V, van Eijk M, Hallman M. Surfactant proteins A and D in eustachian tube epithelium. Am J Physiol Lung Cell Mol Physiol. 2001; 281:L660-L667. [PubMed: 11504694]

58. Madsen J, Kliem A, Tornoe I, Skjodt K, Koch C, Holmskov U. Localization of lung surfactant protein D on mucosal surfaces in human tissues. J Immunol. 2000; 164:5866-5870. [PubMed: 10820266]

59. Stahlman MT, Gray ME, Hull WM, Whitsett JA. Immunolocalization of surfactant protein-D (SPD) in human fetal, newborn, and adult tissues. J Histochem Cytochem. 2002; 50:651-660. [PubMed: 11967276]

60. van Rozendaal BA, van Golde LM, Haagsman HP. Localization and functions of SP-A and SP-D at mucosal surfaces. Pediatr Pathol Mol Med. 2001; 20:319-339. [PubMed: 11486736]

61. Wong CJ, Akiyama J, Allen L, Hawgood S. Localization and developmental expression of surfactant proteins D and A in the respiratory tract of the mouse. Pediatr Res. 1996; 39:930-937. [PubMed: 8725251]

62. Leth-Larsen R, Floridon C, Nielsen O, Holmskov U. Surfactant protein D in the female genital tract. Mol Hum Reprod. 2004; 10:149-154. [PubMed: 14981140]

63. Ramet M, Lofgren J, Alho OP, Hallman M. Surfactant protein-A gene locus associated with recurrent otitis media. J Pediatr. 2001; 138:266-268. [PubMed: 11174628]

64. Murray E, Khamri W, Walker MM, Eggleton P, Moran AP, Ferris JA, et al. Expression of surfactant protein $\mathrm{D}$ in the human gastric mucosa and during Helicobacter pylori infection. Infect Immun. 2002; 70:1481-1487. [PubMed: 11854236]

65. Oberley RE, Ault KA, Neff TL, Khubchandani KR, Crouch EC, Snyder JM. Surfactant proteins A and D enhance the phagocytosis of Chlamydia into THP-1 cells. Am J Physiol Lung Cell Mol Physiol. 2004; 287:L296-L306. [PubMed: 15075250] 
66. Oberley RE, Goss KL, Ault KA, Crouch EC, Snyder JM. Surfactant protein D is present in the human female reproductive tract and inhibits Chlamydia trachomatis infection. Mol Hum Reprod. 2004; 10:861-870. [PubMed: 15489244]

67. Miyamura K, Malhotra R, Hoppe HJ, Reid KB, Phizackerley PJ, Macpherson P, et al. Surfactant proteins A (SP-A) and D (SP-D): levels in human amniotic fluid and localization in the fetal membranes. Biochim Biophys Acta. 1994; 1210:303-307. [PubMed: 8305484]

68. Sin DD, Man SF, Marciniuk DD, Ford G, FitzGerald M, Wong E, et al. The effects of fluticasone with or without salmeterol on systemic biomarkers of inflammation in chronic obstructive pulmonary disease. Am J Respir Crit Care Med. 2008; 177:1207-1214. [PubMed: 18310480]

69. Dulkerian SJ, Gonzales LW, Ning Y, Ballard PL. Regulation of surfactant protein D in human fetal lung. Am J Respir Cell Mol Biol. 1996; 15:781-786. [PubMed: 8969273]

70. White CW, Greene KE, Allen CB, Shannon JM. Elevated expression of surfactant proteins in newborn rats during adaptation to hyperoxia. Am J Respir Cell Mol Biol. 2001; 25:51-59. [PubMed: 11472975]

71. Dave V, Childs T, Whitsett JA. Nuclear factor of activated T cells regulates transcription of the surfactant protein D gene (Sftpd) via direct interaction with thyroid transcription factor-1 in lung epithelial cells. J Biol Chem. 2004; 279:34578-34588. [PubMed: 15173172]

72. Scanlon ST, Milovanova T, Kierstein S, Cao Y, Atochina EN, Tomer Y, et al. Surfactant protein-A inhibits Aspergillus fumigatus-induced allergic T-cell responses. Respir Res. 2005; 6:97. [PubMed: 16120217]

73. Erpenbeck VJ, Schmidt R, Gunther A, Krug N, Hohlfeld JM. Surfactant protein levels in bronchoalveolar lavage after segmental allergen challenge in patients with asthma. Allergy. 2006; 61:598-604. [PubMed: 16629790]

74. Haczku A, Atochina EN, Tomer Y, Chen H, Scanlon ST, Russo S, et al. Aspergillus fumigatusinduced allergic airway inflammation alters surfactant homeostasis and lung function in BALB/c mice. Am J Respir Cell Mol Biol. 2001; 25:45-50. [PubMed: 11472974]

75. Haczku A, Cao Y, Vass G, Kierstein S, Nath P, Atochina-Vasserman EN, et al. IL-4 and IL-13 form a negative feedback circuit with surfactant protein-D in the allergic airway response. $\mathrm{J}$ Immunol. 2006; 176:3557-3565. [PubMed: 16517724]

76. Gonzales LW, Angampalli S, Guttentag SH, Beers MF, Feinstein SI, Matlapudi A, et al. Maintenance of differentiated function of the surfactant system in human fetal lung type II epithelial cells cultured on plastic. Pediatr Pathol Mol Med. 2001; 20:387-412. [PubMed: 11552739]

77. Hoover RR, Floros J. SP-A 39-UTR is involved in the glucocorticoid inhibition of human SP-A gene expression. Am J Physiol. 1999; 276:L917-L924. [PubMed: 10362715]

78. Rust K, Bingle L, Mariencheck W, Persson A, Crouch EC. Characterization of the human surfactant protein D promoter: transcriptional regulation of SP-D gene expression by glucocorticoids. Am J Respir Cell Mol Biol. 1996; 14:121-130. [PubMed: 8630261]

79. Cao Y, Tao JQ, Bates SR, Beers MF, Haczku A. IL-4 induces production of the lung collectin surfactant protein-D. J Allergy Clin Immunol. 2004; 113:439-444. [PubMed: 15007344]

80. Haley KJ, Ciota A, Contreras JP, Boothby MR, Perkins DL, Finn PW. Alterations in lung collectins in an adaptive allergic immune response. Am J Physiol Lung Cell Mol Physiol. 2002; 282:L573-L584. [PubMed: 11839554]

81. Atochina EN, Beers MF, Tomer Y, Scanlon ST, Russo SJ, Panettieri RA Jr, et al. Attenuated allergic airway hyperresponsiveness in C57BL/6 mice is associated with enhanced surfactant protein (SP)-D production following allergic sensitization. Respir Res. 2003; 4:15. [PubMed: 14748931]

82. Kierstein S, Poulain FR, Cao Y, Grous M, Mathias R, Kierstein G, et al. Susceptibility to ozoneinduced airway inflammation is associated with decreased levels of surfactant protein D. Respir Res. 2006; 7:85. [PubMed: 16740162]

83. Takeda K, Haczku A, Lee JJ, Irvin CG, Gelfand EW. Strain dependence of airway hyperresponsiveness reflects differences in eosinophil localization in the lung. Am J Physiol Lung Cell Mol Physiol. 2001; 281:L394-L402. [PubMed: 11435214] 
84. Jain-Vora S, LeVine AM, Chroneos Z, Ross GF, Hull WM, Whitsett JA. Interleukin-4 enhances pulmonary clearance of Pseudomonas aeruginosa. Infect Immun. 1998; 66:4229-4236. [PubMed: 9712772]

85. Mishra A, Weaver TE, Beck DC, Rothenberg ME. Interleukin-5-mediated allergic airway inflammation inhibits the human surfactant protein $\mathrm{C}$ promoter in transgenic mice. J Biol Chem. 2001; 276:8453-8459. [PubMed: 11113143]

86. Homer RJ, Zheng T, Chupp G, He S, Zhu Z, Chen Q, et al. Pulmonary type II cell hypertrophy and pulmonary lipoproteinosis are features of chronic IL-13 exposure. Am J Physiol Lung Cell Mol Physiol. 2002; 283:L52-L59. [PubMed: 12060560]

87. He Y, Crouch EC, Rust K, Spaite E, Brody SL. Proximal promoter of the surfactant protein D gene: regulatory roles of AP-1, forkhead box, and GT box binding proteins. J Biol Chem. 2000; 275:31051-31060. [PubMed: 10915785]

88. He Y, Crouch E. Surfactant protein D gene regulation: interactions among the conserved CCAAT/ enhancer-binding protein elements. J Biol Chem. 2002; 277:19530-19537. [PubMed: 11912209]

89. Lag M, Skarpen E, van Rozendaal BA, Haagsman HP, Huitfeldt HS, Thrane EV, et al. Cellspecific expression of CCAAT/enhancer-binding protein delta (C/EBP delta) in epithelial lung cells. Exp Lung Res. 2000; 26:383-399. [PubMed: 10914335]

90. Martis PC, Whitsett JA, Xu Y, Perl AK, Wan H, Ikegami M. C/EBPalpha is required for lung maturation at birth. Development. 2006; 133:1155-1164. [PubMed: 16467360]

91. Fakhrzadeh L, Laskin JD, Laskin DL. Ozone-induced production of nitric oxide and TNF-alpha and tissue injury are dependent on NF-kappaB p50. Am J Physiol Lung Cell Mol Physiol. 2004; 287:L279-L285. [PubMed: 15064226]

92. Akira S. IL-6-regulated transcription factors. Int J Biochem Cell Biol. 1997; 29:1401-1418. [PubMed: 9570135]

93. Seidel HM, Milocco LH, Lamb P, Darnell JE Jr, Stein RB, Rosen J. Spacing of palindromic half sites as a determinant of selective STAT (signal transducers and activators of transcription) DNA binding and transcriptional activity. Proc Natl Acad Sci U S A. 1995; 92:3041-3045. [PubMed: 7708771]

94. Hodge DR, Hurt EM, Farrar WL. The role of IL-6 and STAT3 in inflammation and cancer. Eur J Cancer. 2005; 41:2502-2512. [PubMed: 16199153]

95. Holmskov U, Jensenius JC. Structure and function of collectins: humoral C-type lectins with collagenous regions. Bernig Inst Mitt. 1993; 3:224-235.

96. Haagsman HP, Diemel RV. Surfactant-associated proteins: functions and structural variation. Comp Biochem Physiol A Mol Integr Physiol. 2001; 129:91-108. [PubMed: 11369536]

97. Hakansson K, Reid KB. Collectin structure: a review. Protein Sci. 2000; 9:1607-1617. [PubMed: 11045608]

98. Kuroki Y, Sano H. Functional roles and structural analysis of lung collectins SP-A and SP-D. Biol Neonate. 1999; 76(suppl 1):19-21. [PubMed: 10393389]

99. Crouch EC. Structure, biologic properties, and expression of surfactant protein D (SP-D). Biochim Biophys Acta. 1998; 1408:278-289. [PubMed: 9813367]

100. Drickamer K, Dordal MS, Reynolds L. Mannose-binding proteins isolated from rat liver contain carbohydrate-recognition domains linked to collagenous tails: complete primary structures and homology with pulmonary surfactant apoprotein. J Biol Chem. 1986; 261:6878-6887. [PubMed: 3009480]

101. Weis WI, Kahn R, Fourme R, Drickamer K, Hendrickson WA. Structure of the calciumdependent lectin domain from a rat mannose-binding protein determined by MAD phasing. Science. 1991; 254:1608-1615. [PubMed: 1721241]

102. Hakansson K, Lim NK, Hoppe HJ, Reid KB. Crystal structure of the trimeric alpha-helical coiledcoil and the three lectin domains of human lung surfactant protein D. Structure Fold Des. 1999; 7:255-264. [PubMed: 10368295]

103. Hoppe HJ, Barlow PN, Reid KB. A parallel three stranded alpha-helical bundle at the nucleation site of collagen triple-helix formation. FEBS Lett. 1994; 344:191-195. [PubMed: 8187882] 
104. Shrive AK, Tharia HA, Strong P, Kishore U, Burns I, Rizkallah PJ, et al. High-resolution structural insights into ligand binding and immune cell recognition by human lung surfactant protein D. J Mol Biol. 2003; 331:509-523. [PubMed: 12888356]

105. Holmskov U, Laursen SB, Malhotra R, Wiedemann H, Timpl R, Stuart GR, et al. Comparative study of the structural and functional properties of a bovine plasma C-type lectin, collectin-43, with other collectins. Biochem J. 1995; 305:889-896. [PubMed: 7848290]

106. Eda S, Suzuki Y, Kawai T, Ohtani K, Kase T, Fujinaga Y, et al. Structure of a truncated human surfactant protein $\mathrm{D}$ is less effective in agglutinating bacteria than the native structure and fails to inhibit haemagglutination by influenza A virus. Biochem J. 1997; 323:393-399. [PubMed: 9163329]

107. Jounblat R, Kadioglu A, Iannelli F, Pozzi G, Eggleton P, Andrew PW. Binding and agglutination of Streptococcus pneumoniae by human surfactant protein D (SP-D) vary between strains, but SP-D fails to enhance killing by neutrophils. Infect Immun. 2004; 72:709-716. [PubMed: 14742512]

108. Schelenz S, Malhotra R, Sim RB, Holmskov U, Bancroft GJ. Binding of host collectins to the pathogenic yeast Cryptococcus neoformans: human surfactant protein $\mathrm{D}$ acts as an agglutinin for acapsular yeast cells. Infect Immun. 1995; 63:3360-3366. [PubMed: 7642263]

109. Hartshorn KL, White MR, Shepherd V, Reid K, Jensenius JC, Crouch EC. Mechanisms of antiinfluenza activity of surfactant proteins A and D: comparison with serum collectins. Am J Physiol. 1997; 273:L1156-L1166. [PubMed: 9435570]

110. Hartshorn KL, Holmskov U, Hansen S, Zhang P, Meschi J, Mogues T, et al. Distinctive antiinfluenza properties of recombinant collectin 43. Biochem J. 2002; 366:87-96. [PubMed: 11971759]

111. Malherbe DC, Erpenbeck VJ, Abraham SN, Crouch EC, Hohlfeld JM, Wright JR. Surfactant protein D decreases pollen-induced IgE-dependent mast cell degranulation. Am J Physiol Lung Cell Mol Physiol. 2005; 289:L856-L866. [PubMed: 15980037]

112. Hartshorn KL, Crouch E, White MR, Colamussi ML, Kakkanatt A, Tauber B, et al. Pulmonary surfactant proteins A and D enhance neutrophil uptake of bacteria. Am J Physiol. 1998; 274:L958-L969. [PubMed: 9609735]

113. Ferguson JS, Voelker DR, McCormack FX, Schlesinger LS. Surfactant protein D binds to Mycobacterium tuberculosis bacilli and lipoarabinomannan via carbohydrate-lectin interactions resulting in reduced phagocytosis of the bacteria by macrophages. J Immunol. 1999; 163:312321. [PubMed: 10384130]

114. Ferguson JS, Voelker DR, Ufnar JA, Dawson AJ, Schlesinger LS. Surfactant protein D inhibition of human macrophage uptake of Mycobacterium tuberculosis is independent of bacterial agglutination. J Immunol. 2002; 168:1309-1314. [PubMed: 11801670]

115. Hartshorn K, Chang D, Rust K, White M, Heuser J, Crouch E. Interactions of recombinant human pulmonary surfactant protein D and SP-D multimers with influenza A. Am J Physiol. 1996; 271:L753-L762. [PubMed: 8944718]

116. Hartshorn KL, Reid KB, White MR, Jensenius JC, Morris SM, Tauber AI, et al. Neutrophil deactivation by influenza Aviruses: mechanisms of protection after viral opsonization with collectins and hemagglutination-inhibiting antibodies. Blood. 1996; 87:3450-3461. [PubMed: 8605364]

117. Crouch E, Chang D, Rust K, Persson A, Heuser J. Recombinant pulmonary surfactant protein D: post-translational modification and molecular assembly. J Biol Chem. 1994; 269:15808-15813. [PubMed: 8195236]

118. Ogasawara Y, Voelker DR. The role of the amino-terminal domain and the collagenous region in the structure and the function of rat surfactant protein D. J Biol Chem. 1995; 270:19052-19058. [PubMed: 7642568]

119. Kawasaki T, Etoh R, Yamashina I. Isolation and characterization of a mannan-binding protein from rabbit liver. Biochem Biophys Res Commun. 1978; 81:1018-1024. [PubMed: 666781]

120. Kolatkar AR, Weis WI. Structural basis of galactose recognition by C-type animal lectins. J Biol Chem. 1996; 271:6679-6685. [PubMed: 8636086] 
121. Allen MJ, Harbeck R, Smith B, Voelker DR, Mason RJ. Binding of rat and human surfactant proteins A and D to Aspergillus fumigatus conidia. Infect Immun. 1999; 67:4563-4569. [PubMed: 10456901]

122. Allen MJ, Voelker DR, Mason RJ. Interactions of surfactant proteins A and D with Saccharomyces cerevisiae and Aspergillus fumigatus. Infect Immun. 2001; 69:2037-2044. [PubMed: 11254556]

123. Allen MJ, Laederach A, Reilly PJ, Mason RJ. Polysaccharide recognition by surfactant protein D: novel interactions of a C-type lectin with nonterminal glucosyl residues. Biochemistry. 2001; 40:7789-7798. [PubMed: 11425305]

124. Madan T, Eggleton P, Kishore U, Strong P, Aggrawal SS, Sarma PU, et al. Binding of pulmonary surfactant proteins A and D to Aspergillus fumigatus conidia enhances phagocytosis and killing by human neutrophils and alveolar macrophages. Infect Immun. 1997; 65:3171-3179. [PubMed: 9234771]

125. Haurum JS, Thiel S, Haagsman HP, Laursen SB, Larsen B, Jensenius JC. Studies on the carbohydrate-binding characteristics of human pulmonary surfactant-associated protein A and comparison with two other collectins: mannan-binding protein and conglutinin. Biochem J. 1993; 293:873-878. [PubMed: 8352755]

126. Crouch EC. Collectins and pulmonary host defense. Am J Respir Cell Mol Biol. 1998; 19:177201. [PubMed: 9698590]

127. Lim BL, Wang JY, Holmskov U, Hoppe HJ, Reid KB. Expression of the carbohydrate recognition domain of lung surfactant protein $\mathrm{D}$ and demonstration of its binding to lipopolysaccharides of gram-negative bacteria. Biochem Biophys Res Commun. 1994; 202:1674-1680. [PubMed: 8060356]

128. Saitoh M, Sano H, Chiba H, Murakami S, Iwaki D, Sohma H, et al. Importance of the carboxyterminal 25 amino acid residues of lung collectins in interactions with lipids and alveolar type II cells. Biochemistry. 2000; 39:1059-1066. [PubMed: 10653651]

129. Haagsman HP. Surfactant proteins A and D. Biochem Soc Trans. 1994; 22:100-106. [PubMed: 8206199]

130. Haagsman HP. Interactions of surfactant protein A with pathogens. Biochim Biophys Acta. 1998; 1408:264-277. [PubMed: 9813361]

131. Ogasawara Y, McCormack FX, Mason RJ, Voelker DR. Chimeras of surfactant proteins A and D identify the carbohydrate recognition domains as essential for phospholipid interaction. J Biol Chem. 1994; 269:29785-29792. [PubMed: 7961971]

132. Ikegami M, Korfhagen TR, Whitsett JA, Bruno MD, Wert SE, Wada K, et al. Characteristics of surfactant from SP-A-deficient mice. Am J Physiol. 1998; 275:L247-L254. [PubMed: 9700084]

133. Korfhagen TR, LeVine AM, Whitsett JA. Surfactant protein A (SP-A) gene targeted mice. Biochim Biophys Acta. 1998; 1408:296-302. [PubMed: 9813377]

134. Palaniyar N, Zhang L, Kuzmenko A, Ikegami M, Wan S, Wu H, et al. The role of pulmonary collectin N-terminal domains in surfactant structure, function, and homeostasis in vivo. J Biol Chem. 2002; 277:26971-26979. [PubMed: 12015304]

135. Palaniyar N, Clark H, Nadesalingam J, Hawgood S, Reid KB. Surfactant protein D binds genomic DNA and apoptotic cells, and enhances their clearance, in vivo. Ann N Y Acad Sci. 2003; 1010:471-475. [PubMed: 15033772]

136. Palaniyar N, Nadesalingam J, Clark H, Shih MJ, Dodds AW, Reid KB. Nucleic acid is a novel ligand for innate immune pattern recognition collectins surfactant proteins $\mathrm{A}$ and $\mathrm{D}$ and mannose-binding lectin. J Biol Chem. 2004; 279:32728-32736. [PubMed: 15145932]

137. Vandivier RW, Ogden CA, Fadok VA, Hoffmann PR, Brown KK, Botto M, et al. Role of surfactant proteins A, D, and C1q in the clearance of apoptotic cells in vivo and in vitro: calreticulin and CD91 as a common collectin receptor complex. J Immunol. 2002; 169:39783986. [PubMed: 12244199]

138. Cheng G, Ueda T, Nakajima H, Nakajima A, Arima M, Kinjyo S, et al. Surfactant protein A exhibits inhibitory effect on eosinophils IL-8 production. Biochem Biophys Res Commun. 2000; 270:831-835. [PubMed: 10772911] 
139. Nauta AJ, Raaschou-Jensen N, Roos A, Daha MR, Madsen HO, Borrias-Essers MC, et al. Mannose-binding lectin engagement with late apoptotic and necrotic cells. Eur J Immunol. 2003; 33:2853-2863. [PubMed: 14515269]

140. Schagat TL, Wofford JA, Wright JR. Surfactant protein A enhances alveolar macrophage phagocytosis of apoptotic neutrophils. J Immunol. 2001; 166:2727-2733. [PubMed: 11160338]

141. Gordon S. Pattern recognition receptors: doubling up for the innate immune response. Cell. 2002; 111:927-930. [PubMed: 12507420]

142. Beharka AA, Gaynor CD, Kang BK, Voelker DR, McCormack FX, Schlesinger LS. Pulmonary surfactant protein A up-regulates activity of the mannose receptor, a pattern recognition receptor expressed on human macrophages. J Immunol. 2002; 169:3565-3573. [PubMed: 12244146]

143. Schaub B, Westlake RM, He H, Arestides R, Haley KJ, Campo M, et al. Surfactant protein D deficiency influences allergic immune responses. Clin Exp Allergy. 2004; 34:1819-1826. [PubMed: 15663554]

144. Restrepo CI, Dong Q, Savov J, Mariencheck WI, Wright JR. Surfactant protein D stimulates phagocytosis of Pseudomonas aeruginosa by alveolar macrophages. Am J Respir Cell Mol Biol. 1999; 21:576-585. [PubMed: 10536117]

145. Ofek I, Mesika A, Kalina M, Keisari Y, Podschun R, Sahly H, et al. Surfactant protein D enhances phagocytosis and killing of unencapsulated phase variants of Klebsiella pneumoniae. Infect Immun. 2001; 69:24-33. [PubMed: 11119485]

146. Gaynor CD, McCormack FX, Voelker DR, McGowan SE, Schlesinger LS. Pulmonary surfactant protein A mediates enhanced phagocytosis of Mycobacterium tuberculosis by a direct interaction with human macrophages. J Immunol. 1995; 155:5343-5351. [PubMed: 7594549]

147. Weikert LF, Edwards K, Chroneos ZC, Hager C, Hoffman L, Shepherd VL. SP-A enhances uptake of bacillus Calmette-Guerin by macrophages through a specific SP-A receptor. Am J Physiol. 1997; 272:L989-L995. [PubMed: 9176265]

148. LeVine AM, Bruno MD, Huelsman KM, Ross GF, Whitsett JA, Korfhagen TR. Surfactant protein A-deficient mice are susceptible to group B streptococcal infection. J Immunol. 1997; 158:4336-4340. [PubMed: 9126996]

149. LeVine AM, Kurak KE, Wright JR, Watford WT, Bruno MD, Ross GF, et al. Surfactant proteinA binds group B streptococcus enhancing phagocytosis and clearance from lungs of surfactant protein-A-deficient mice. Am J Respir Cell Mol Biol. 1999; 20:279-286. [PubMed: 9922219]

150. LeVine AM, Kurak KE, Bruno MD, Stark JM, Whitsett JA, Korfhagen TR. Surfactant protein-Adeficient mice are susceptible to Pseudomonas aeruginosa infection. Am J Respir Cell Mol Biol. 1998; 19:700-708. [PubMed: 9761768]

151. Van Rozendaal BA, Van de Lest CH, Van Eijk M, Van Helden HP, Haagsman HP. Pulmonary surfactant proteins A and D are involved in the early response to intratracheally aerosolized lipopolysaccharide. Biochem Soc Trans. 1997; 25:S656. [PubMed: 9450084]

152. Sahly H, Ofek I, Podschun R, Brade H, He Y, Ullmann U, et al. Surfactant protein D binds selectively to Klebsiella pneumoniae lipopolysaccharides containing mannose-rich O-antigens. J Immunol. 2002; 169:3267-3274. [PubMed: 12218146]

153. Van Iwaarden JF, Pikaar JC, Storm J, Brouwer E, Verhoef J, Oosting RS, et al. Binding of surfactant protein A to the lipid A moiety of bacterial lipopolysaccharides. Biochem J. 1994; 303:407-411. [PubMed: 7980398]

154. Malhotra R, Haurum JS, Thiel S, Sim RB. Binding of human collectins (SP-A and MBP) to influenza virus. Biochem J. 1994; 304:455-461. [PubMed: 7998980]

155. Benne CA, Kraaijeveld CA, van Strijp JA, Brouwer E, Harmsen M, Verhoef J, et al. Interactions of surfactant protein A with influenza A viruses: binding and neutralization. J Infect Dis. 1995; 171:335-341. [PubMed: 7844369]

156. Hartshorn KL, White MR, Voelker DR, Coburn J, Zaner K, Crouch EC. Mechanism of binding of surfactant protein D to influenza A viruses: importance of binding to haemagglutinin to antiviral activity. Biochem J. 2000; 351:449-458. [PubMed: 11023831]

157. Hartshorn KL, Crouch EC, White MR, Eggleton P, Tauber AI, Chang D, et al. Evidence for a protective role of pulmonary surfactant protein D (SP-D) against influenza A viruses. J Clin Invest. 1994; 94:311-319. [PubMed: 8040272] 
158. Ghildyal R, Hartley C, Varrasso A, Meanger J, Voelker DR, Anders EM, et al. Surfactant protein A binds to the fusion glycoprotein of respiratory syncytial virus and neutralizes virion infectivity. J Infect Dis. 1999; 180:2009-2013. [PubMed: 10558959]

159. Hickling TP, Bright H, Wing K, Gower D, Martin SL, Sim RB, et al. A recombinant trimeric surfactant protein $\mathrm{D}$ carbohydrate recognition domain inhibits respiratory syncytial virus infection in vitro and in vivo. Eur J Immunol. 1999; 29:3478-3484. [PubMed: 10556802]

160. Deitsch KW, Moxon ER, Wellems TE. Shared themes of antigenic variation and virulence in bacterial, protozoal, and fungal infections. Microbiol Mol Biol Rev. 1997; 61:281-293. [PubMed: 9293182]

161. van de Wetering JK, Coenjaerts FE, Vaandrager AB, van Golde LM, Batenburg JJ. Aggregation of Cryptococcus neoformans by surfactant protein $\mathrm{D}$ is inhibited by its capsular component glucuronoxylomannan. Infect Immun. 2004; 72:145-153. [PubMed: 14688091]

162. Walenkamp AM, Verheul AF, Scharringa J, Hoepelman IM. Pulmonary surfactant protein A binds to Cryptococcus neoformans without promoting phagocytosis. Eur J Clin Invest. 1999; 29:83-92. [PubMed: 10092994]

163. Rosseau S, Guenther A, Seeger W, Lohmeyer J. Phagocytosis of viable Candida albicans by alveolar macrophages: lack of opsonin function of surfactant protein A. J Infect Dis. 1997; 175:421-428. [PubMed: 9203664]

164. Koziel H, Phelps DS, Fishman JA, Armstrong MY, Richards FF, Rose RM. Surfactant protein-A reduces binding and phagocytosis of pneumocystis carinii by human alveolar macrophages in vitro. Am J Respir Cell Mol Biol. 1998; 18:834-843. [PubMed: 9618388]

165. Linke MJ, Harris CE, Korfhagen TR, McCormack FX, Ashbaugh AD, Steele P, et al. Immunosuppressed surfactant protein A-deficient mice have increased susceptibility to Pneumocystis carinii infection. J Infect Dis. 2001; 183:943-952. [PubMed: 11237812]

166. Vuk-Pavlovic Z, Standing JE, Crouch EC, Limper AH. Carbohydrate recognition domain of surfactant protein D mediates interactions with Pneumocystis carinii glycoprotein A. Am J Respir Cell Mol Biol. 2001; 24:475-484. [PubMed: 11306442]

167. Yong SJ, Vuk-Pavlovic Z, Standing JE, Crouch EC, Limper AH. Surfactant protein D-mediated aggregation of Pneumocystis carinii impairs phagocytosis by alveolar macrophages. Infect Immun. 2003; 71:1662-1671. [PubMed: 12654779]

168. Postle AD, Mander A, Reid KB, Wang JY, Wright SM, Moustaki M, et al. Deficient hydrophilic lung surfactant proteins $A$ and D with normal surfactant phospholipid molecular species in cystic fibrosis. Am J Respir Cell Mol Biol. 1999; 20:90-98. [PubMed: 9870921]

169. Madan T, Kishore U, Singh M, Strong P, Clark H, Hussain EM, et al. Surfactant proteins A and D protect mice against pulmonary hypersensitivity induced by Aspergillus fumigatus antigens and allergens. J Clin Invest. 2001; 107:467-475. [PubMed: 11181646]

170. Madan T, Kishore U, Singh M, Strong P, Hussain EM, Reid KB, et al. Protective role of lung surfactant protein D in a murine model of invasive pulmonary aspergillosis. Infect Immun. 2001; 69:2728-2731. [PubMed: 11254642]

171. Kishor U, Madan T, Sarma PU, Singh M, Urban BC, Reid KB. Protective roles of pulmonary surfactant proteins, SP-A and SP-D, against lung allergy and infection caused by Aspergillus fumigatus. Immunobiology. 2002; 205:610-618. [PubMed: 12396019]

172. Strong P, Reid KB, Clark H. Intranasal delivery of a truncated recombinant human SP-D is effective at down-regulating allergic hypersensitivity in mice sensitized to allergens of Aspergillus fumigatus. Clin Exp Immunol. 2002; 130:19-24. [PubMed: 12296848]

173. Strong P, Townsend P, Mackay R, Reid KB, Clark HW. A recombinant fragment of human SP-D reduces allergic responses in mice sensitized to house dust mite allergens. Clin Exp Immunol. 2003; 134:181-187. [PubMed: 14616775]

174. Saxena S, Madan T, Shah A, Muralidhar K, Sarma PU. Association of polymorphisms in the collagen region of SP-A2 with increased levels of total IgE antibodies and eosinophilia in patients with allergic bronchopulmonary aspergillosis. J Allergy Clin Immunol. 2003; 111:10011007. [PubMed: 12743564] 
175. Malhotra R, Haurum J, Thiel S, Jensenius JC, Sim RB. Pollen grains bind to lung alveolar type II cells (A549) via lung surfactant protein A (SP-A). Biosci Rep. 1993; 13:79-90. [PubMed: 8374060]

176. Erpenbeck VJ, Malherbe DC, Sommer S, Schmiedl A, Steinhilber W, Ghio AJ, et al. Surfactant protein D increases phagocytosis and aggregation of pollen-allergen starch granules. Am J Physiol Lung Cell Mol Physiol. 2005; 288:L692-L698. [PubMed: 15591410]

177. Wang JY, Kishore U, Lim BL, Strong P, Reid KB. Interaction of human lung surfactant proteins A and D with mite (Dermatophagoides pteronyssinus) allergens. Clin Exp Immunol. 1996; 106:367-373. [PubMed: 8918587]

178. Deb R, Shakib F, Reid K, Clark H. Major house dust mite allergens Dermatophagoides pteronyssinus 1 and Dermatophagoides farinae 1 degrade and inactivate lung surfactant proteins A and D. J Biol Chem. 2007; 282:36808-36819. [PubMed: 17848554]

179. Wang JY, Shieh CC, You PF, Lei HY, Reid KB. Inhibitory effect of pulmonary surfactant proteins $\mathrm{A}$ and $\mathrm{D}$ on allergen-induced lymphocyte proliferation and histamine release in children with asthma. Am J Respir Crit Care Med. 1998; 158:510-518. [PubMed: 9700129]

180. Hohlfeld JM, Erpenbeck VJ, Krug N. Surfactant proteins SP-A and SP-D as modulators of the allergic inflammation in asthma. Pathobiology. 2002; 70:287-292. [PubMed: 12771511]

181. McGreal E, Gasque P. Structure-function studies of the receptors for complement C1q. Biochem Soc Trans. 2002; 30:1010-1014. [PubMed: 12440963]

182. Henson PM, Bratton DL, Fadok VA. The phosphatidylserine receptor: a crucial molecular switch? Nat Rev Mol Cell Biol. 2001; 2:627-633. [PubMed: 11483996]

183. Kuroki Y, Takahashi M, Nishitani C. Pulmonary collectins in innate immunity of the lung. Cell Microbiol. 2007; 9:1871-1879. [PubMed: 17490408]

184. Ackerman AL, Kyritsis C, Tampe R, Cresswell P. Early phagosomes in dendritic cells form a cellular compartment sufficient for cross presentation of exogenous antigens. Proc Natl Acad Sci U S A. 2003; 100:12889-12894. [PubMed: 14561893]

185. Gardai SJ, Xiao YQ, Dickinson M, Nick JA, Voelker DR, Greene KE, et al. By binding SIRPalpha or calreticulin/CD91, lung collectins act as dual function surveillance molecules to suppress or enhance inflammation. Cell. 2003; 115:13-23. [PubMed: 14531999]

186. Chroneos ZC, Abdolrasulnia R, Whitsett JA, Rice WR, Shepherd VL. Purification of a cellsurface receptor for surfactant protein A. J Biol Chem. 1996; 271:16375-16383. [PubMed: 8663107]

187. Weikert LF, Lopez JP, Abdolrasulnia R, Chroneos ZC, Shepherd VL. Surfactant protein A enhances mycobacterial killing by rat macrophages through a nitric oxide-dependent pathway. Am J Physiol Lung Cell Mol Physiol. 2000; 279:L216-L223. [PubMed: 10926544]

188. Holmskov U, Lawson P, Teisner B, Tornoe I, Willis AC, Morgan C, et al. Isolation and characterization of a new member of the scavenger receptor superfamily, glycoprotein-340 (gp-340), as a lung surfactant protein-D binding molecule. J Biol Chem. 1997; 272:1374313749. [PubMed: 9153228]

189. Tino MJ, Wright JR. Glycoprotein-340 binds surfactant protein-A (SP-A) and stimulates alveolar macrophage migration in an SP-A-independent manner. Am J Respir Cell Mol Biol. 1999; 20:759-768. [PubMed: 10101009]

190. Madsen J, Tornoe I, Nielsen O, Lausen M, Krebs I, Mollenhauer J, et al. CRP-ductin, the mouse homologue of gp-340/deleted in malignant brain tumors(DMBT1), binds gram-positive and gram-negative bacteria and interacts with lung surfactant protein D. Eur J Immunol. 2003; 33:2327-2336. [PubMed: 12884308]

191. Hartshorn KL, White MR, Mogues T, Ligtenberg T, Crouch E, Holmskov U. Lung and salivary scavenger receptor glycoprotein-340 contribute to the host defense against influenza A viruses. Am J Physiol Lung Cell Mol Physiol. 2003; 285:L1066-L1076. [PubMed: 12871854]

192. Ligtenberg TJ, Bikker FJ, Groenink J, Tornoe I, Leth-Larsen R, Veerman EC, et al. Human salivary agglutinin binds to lung surfactant protein-D and is identical with scavenger receptor protein gp-340. Biochem J. 2001; 359:243-248. [PubMed: 11563989] 
193. Crouch EC, Persson A, Griffin GL, Chang D, Senior RM. Interactions of pulmonary surfactant protein D (SP-D) with human blood leukocytes. Am J Respir Cell Mol Biol. 1995; 12:410-415. [PubMed: 7695920]

194. Sano H, Chiba H, Iwaki D, Sohma H, Voelker DR, Kuroki Y. Surfactant proteins A and D bind CD14 by different mechanisms. J Biol Chem. 2000; 275:22442-22451. [PubMed: 10801802]

195. Chiba H, Sano H, Iwaki D, Murakami S, Mitsuzawa H, Takahashi T, et al. Rat mannose-binding protein a binds CD14. Infect Immun. 2001; 69:1587-1592. [PubMed: 11179331]

196. Murakami S, Iwaki D, Mitsuzawa H, Sano H, Takahashi H, Voelker DR, et al. Surfactant protein A inhibits peptidoglycan-induced tumor necrosis factor-alpha secretion in U937 cells and alveolar macrophages by direct interaction with toll-like receptor 2. J Biol Chem. 2002; 277:6830-6837. [PubMed: 11724772]

197. Ohya M, Nishitani C, Sano H, Yamada C, Mitsuzawa H, Shimizu T, et al. Human pulmonary surfactant protein D binds the extracellular domains of Toll-like receptors-2 and 4 through the carbohydrate recognition domain by a mechanism different from its binding to phosphatidylinositol and lipopolysaccharide. Biochemistry. 2006; 45:8657-8664. [PubMed: 16834340]

198. Guillot L, Balloy V, McCormack FX, Golenbock DT, Chignard M, Si-Tahar M. Cutting edge: the immunostimulatory activity of the lung surfactant protein-A involves Toll-like receptor 4 . J Immunol. 2002; 168:5989-5992. [PubMed: 12055204]

199. Janssen WJ, McPhillips KA, Dickinson MG, Linderman DJ, Morimoto K, Xiao YQ, et al. Surfactant proteins A and D suppress alveolar macrophage phagocytosis via interaction with SIRP alpha. Am J Respir Crit Care Med. 2008; 178:158-167. [PubMed: 18420961]

200. Rosseau S, Hammerl P, Maus U, Gunther A, Seeger W, Grimminger F, et al. Surfactant protein A down-regulates proinflammatory cytokine production evoked by Candida albicans in human alveolar macrophages and monocytes. J Immunol. 1999; 163:4495-4502. [PubMed: 10510392]

201. Gold JA, Hoshino Y, Tanaka N, Rom WN, Raju B, Condos R, et al. Surfactant protein A modulates the inflammatory response in macrophages during tuberculosis. Infect Immun. 2004; 72:645-650. [PubMed: 14742504]

202. Yoshida M, Whitsett JA. Alveolar macrophages and emphysema in surfactant protein-D-deficient mice. Respirology. 2006; 11(suppl):S37-S40. [PubMed: 16423269]

203. Hortobagyi L, Kierstein S, Krytska K, Zhu X, Das AM, Poulain F, et al. Surfactant protein D inhibits TNF-alpha production by macrophages and dendritic cells in mice. J Allergy Clin Immunol. 2008; 122:521-528. [PubMed: 18554706]

204. Barr FE, Pedigo H, Johnson TR, Shepherd VL. Surfactant protein-A enhances uptake of respiratory syncytial virus by monocytes and U937 macrophages. Am J Respir Cell Mol Biol. 2000; 23:586-592. [PubMed: 11062136]

205. McIntosh JC, Mervin-Blake S, Conner E, Wright JR. Surfactant protein A protects growing cells and reduces TNF-alpha activity from LPS-stimulated macrophages. Am J Physiol. 1996; 271:L310-L319. [PubMed: 8770070]

206. Sano H, Sohma H, Muta T, Nomura S, Voelker DR, Kuroki Y. Pulmonary surfactant protein A modulates the cellular response to smooth and rough lipopolysaccharides by interaction with CD14. J Immunol. 1999; 163:387-395. [PubMed: 10384140]

207. Takeda K, Miyahara N, Rha YH, Taube C, Yang ES, Joetham A, et al. Surfactant protein D regulates airway function and allergic inflammation through modulation of macrophage function. Am J Respir Crit Care Med. 2003; 168:783-789. [PubMed: 12882759]

208. van Iwaarden JF, Shimizu H, Van Golde PH, Voelker DR, Van Golde LM. Rat surfactant protein D enhances the production of oxygen radicals by rat alveolar macrophages. Biochem J. 1992; 286:5-8. [PubMed: 1325783]

209. Weissbach S, Neuendank A, Pettersson M, Schaberg T, Pison U. Surfactant protein A modulates release of reactive oxygen species from alveolar macrophages. Am J Physiol. 1994; 267:L660 L666. [PubMed: 7810671]

210. van Iwaarden F, Welmers B, Verhoef J, Haagsman HP, van Golde LM. Pulmonary surfactant protein A enhances the host-defense mechanism of rat alveolar macrophages. Am J Respir Cell Mol Biol. 1990; 2:91-98. [PubMed: 2306370] 
211. Atochina EN, Gow AJ, Beck JM, Haczku A, Inch A, Kadire H, et al. Delayed clearance of Pneumocystis carinii infection, increased inflammation, and altered nitric oxide metabolism in lungs of surfactant protein-D knockout mice. J Infect Dis. 2004; 189:1528-1539. [PubMed: 15073692]

212. Liu CF, Chen YL, Shieh CC, Yu CK, Reid KB, Wang JY. Therapeutic effect of surfactant protein D in allergic inflammation of mite-sensitized mice. Clin Exp Allergy. 2005; 35:515-521. [PubMed: 15836762]

213. Bridges JP, Davis HW, Damodarasamy M, Kuroki Y, Howles G, Hui DY, et al. Pulmonary surfactant proteins A and D are potent endogenous inhibitors of lipid peroxidation and oxidative cellular injury. J Biol Chem. 2000; 275:38848-38855. [PubMed: 10969075]

214. Wright JR, Youmans DC. Pulmonary surfactant protein A stimulates chemotaxis of alveolar macrophage. Am J Physiol. 1993; 264:L338-L344. [PubMed: 8476070]

215. Tino MJ, Wright JR. Surfactant proteins A and D specifically stimulate directed actin-based responses in alveolar macrophages. Am J Physiol. 1999; 276:L164-L174. [PubMed: 9887069]

216. Brinker KG, Martin E, Borron P, Mostaghel E, Doyle C, Harding CV, et al. Surfactant protein D enhances bacterial antigen presentation by bone marrow-derived dendritic cells. Am J Physiol Lung Cell Mol Physiol. 2001; 281:L1453-L1463. [PubMed: 11704542]

217. Brinker KG, Garner H, Wright JR. Surfactant protein A modulates the differentiation of murine bone marrow-derived dendritic cells. Am J Physiol Lung Cell Mol Physiol. 2003; 284:L232L241. [PubMed: 12388334]

218. Hansen S, Lo B, Evans K, Neophytou P, Holmskov U, Wright JR. Surfactant protein D augments bacterial association but attenuates major histocompatibility complex class II presentation of bacterial antigens. Am J Respir Cell Mol Biol. 2007; 36:94-102. [PubMed: 16902193]

219. Gallucci S, Matzinger P. Danger signals: SOS to the immune system. Curr Opin Immunol. 2001; 13:114-119. [PubMed: 11154927]

220. Wu L, Liu YJ. Development of dendritic-cell lineages. Immunity. 2007; 26:741-750. [PubMed: 17582346]

221. Grayson MH, Ramos MS, Rohlfing MM, Kitchens R, Wang HD, Gould A, et al. Controls for lung dendritic cell maturation and migration during respiratory viral infection. J Immunol. 2007; 179:1438-1448. [PubMed: 17641009]

222. Lambrecht BN, De Veerman M, Coyle AJ, Gutierrez-Ramos JC, Thielemans K, Pauwels RA. Myeloid dendritic cells induce Th2 responses to inhaled antigen, leading to eosinophilic airway inflammation. J Clin Invest. 2000; 106:551-559. [PubMed: 10953030]

223. Kohl K, Schnautz S, Pesch M, Klein E, Aumailley M, Bieber T, et al. Subpopulations of human dendritic cells display a distinct phenotype and bind differentially to proteins of the extracellular matrix. Eur J Cell Biol. 2007; 86:719-730. [PubMed: 17689829]

224. Kohl J, Wills-Karp M. Complement regulates inhalation tolerance at the dendritic cell/T cell interface. Mol Immunol. 2007; 44:44-56. [PubMed: 16889830]

225. Wilsher ML, Hughes DA, Haslam PL. Immunoregulatory properties of pulmonary surfactant: effect of lung lining fluid on proliferation of human blood lymphocytes. Thorax. 1988; 43:354359. [PubMed: 3194863]

226. Wilsher ML, Parker DJ, Haslam PL. Immunosuppression by pulmonary surfactant: mechanisms of action. Thorax. 1990; 45:3-8. [PubMed: 2321174]

227. Wilsher ML, Hughes DA, Haslam PL. Immunomodulatory effects of pulmonary surfactant on natural killer cell and antibody-dependent cytotoxicity. Clin Exp Immunol. 1988; 74:465-470. [PubMed: 3069255]

228. LeVine AM, Hartshorn K, Elliott J, Whitsett J, Korfhagen T. Absence of SP-A modulates innate and adaptive defense responses to pulmonary influenza infection. Am J Physiol Lung Cell Mol Physiol. 2002; 282:L563-L572. [PubMed: 11839553]

229. Borron P, Veldhuizen RA, Lewis JF, Possmayer F, Caveney A, Inchley K, et al. Surfactant associated protein-A inhibits human lymphocyte proliferation and IL-2 production. Am J Respir Cell Mol Biol. 1996; 15:115-121. [PubMed: 8679215] 
230. Borron P, McCormack FX, Elhalwagi BM, Chroneos ZC, Lewis JF, Zhu S, et al. Surfactant protein A inhibits T cell proliferation via its collagen-like tail and a 210-kDa receptor. Am J Physiol. 1998; 275:L679-L686. [PubMed: 9755099]

231. Borron PJ, Crouch EC, Lewis JF, Wright JR, Possmayer F, Fraher LJ. Recombinant rat surfactant-associated protein D inhibits human T lymphocyte proliferation and IL-2 production. J Immunol. 1998; 161:4599-4603. [PubMed: 9794387]

232. Vass G, Scanlon ST, Beers MF, Haczku A. Surfactant protein (SP)-D suppresses antigenic and mitogenic T cell activation in vitro. J Allergy Clin Immunol. 2004; 113:S252.

233. Borron PJ, Mostaghel EA, Doyle C, Walsh ES, McHeyzer-Williams MG, Wright JR. Pulmonary surfactant proteins A and D directly suppress CD31/CD41 cell function: evidence for two shared mechanisms. J Immunol. 2002; 169:5844-5850. [PubMed: 12421966]

234. Singh M, Madan T, Waters P, Parida SK, Sarma PU, Kishore U. Protective effects of a recombinant fragment of human surfactant protein $\mathrm{D}$ in a murine model of pulmonary hypersensitivity induced by dust mite allergens. Immunol Lett. 2003; 86:299-307. [PubMed: 12706535]

235. Brandt EB, Mingler MK, Stevenson MD, Wang N, Khurana Hershey GK, Whitsett JA, et al. Surfactant protein D alters allergic lung responses in mice and human subjects. J Allergy Clin Immunol. 2008; 121:1140-1147. e2. [PubMed: 18355911]

236. Turner MW. The role of mannose-binding lectin in health and disease. Mol Immunol. 2003; 40:423-429. [PubMed: 14568388]

237. Hallman M, Haataja R. Surfactant protein polymorphisms and neonatal lung disease. Semin Perinatol. 2006; 30:350-361. [PubMed: 17142161]

238. Thiel S, Frederiksen PD, Jensenius JC. Clinical manifestations of mannan-binding lectin deficiency. Mol Immunol. 2006; 43:86-96. [PubMed: 16023210]

239. Pastva AM, Wright JR, Williams KL. Immunomodulatory roles of surfactant proteins A and D: implications in lung disease. Proc Am Thorac Soc. 2007; 4:252-257. [PubMed: 17607008]

240. Hoover RR, Floros J. Organization of the human SP-A and SP-D loci at 10q22-q23. Physical and radiation hybrid mapping reveal gene order and orientation. Am J Respir Cell Mol Biol. 1998; 18:353-362. [PubMed: 9490653]

241. Floros J, Hoover RR. Genetics of the hydrophilic surfactant proteins A and D. Biochim Biophys Acta. 1998; 1408:312-322. [PubMed: 9813381]

242. Krizkova L, Sakthivel R, Olowe SA, Rogan PK, Floros J. Human SP-A: genotype and singlestrand conformation polymorphism analysis. Am J Physiol. 1994; 266:L519-L527. [PubMed: 8203545]

243. Rishi A, Hatzis D, McAlmon K, Floros J. An allelic variant of the 6A gene for human surfactant protein A. Am J Physiol. 1992; 262:L566-L573. [PubMed: 1590407]

244. Mikerov AN, Wang G, Umstead TM, Zacharatos M, Thomas NJ, Phelps DS, et al. Surfactant protein A2 (SP-A2) variants expressed in CHO cells stimulate phagocytosis of Pseudomonas aeruginosa more than do SP-A1 variants. Infect Immun. 2007; 75:1403-1412. [PubMed: 17220308]

245. Mikerov AN, Umstead TM, Gan X, Huang W, Guo X, Wang G, et al. Impact of ozone exposure on the phagocytic activity of human surfactant protein A (SP-A) and SP-A variants. Am J Physiol Lung Cell Mol Physiol. 2008; 294:L121-L130. [PubMed: 17981957]

246. Oberley RE, Snyder JM. Recombinant human SP-A1 and SP-A2 proteins have different carbohydrate-binding characteristics. Am J Physiol Lung Cell Mol Physiol. 2003; 284:L871L881. [PubMed: 12505869]

247. Wang G, Bates-Kenney SR, Tao JQ, Phelps DS, Floros J. Differences in biochemical properties and in biological function between human SP-A1 and SPA2 variants, and the impact of ozoneinduced oxidation. Biochemistry. 2004; 43:4227-4239. [PubMed: 15065867]

248. Wang G, Phelps DS, Umstead TM, Floros J. Human SP-A protein variants derived from one or both genes stimulate TNF-alpha production in the THP-1 cell line. Am J Physiol Lung Cell Mol Physiol. 2000; 278:L946-L954. [PubMed: 10781424] 
249. Wang G, Umstead TM, Phelps DS, Al-Mondhiry H, Floros J. The effect of ozone exposure on the ability of human surfactant protein a variants to stimulate cytokine production. Environ Health Perspect. 2002; 110:79-84. [PubMed: 11781168]

250. DiAngelo S, Lin Z, Wang G, Phillips S, Ramet M, Luo J, et al. Novel, non-radioactive, simple and multiplex PCR-cRFLP methods for genotyping human SP-A and SP-D marker alleles. Dis Markers. 1999; 15:269-281. [PubMed: 10689550]

251. Tagaram HR, Wang G, Umstead TM, Mikerov AN, Thomas NJ, Graff GR, et al. Characterization of a human surfactant protein A1 (SP-A1) gene-specific antibody; SP-A1 content variation among individuals of varying age and pulmonary health. Am J Physiol Lung Cell Mol Physiol. 2007; 292:L1052-L1063. [PubMed: 17189324]

252. Wang G, Guo X, Floros J. Human SP-A 39-UTR variants mediate differential gene expression in basal levels and in response to dexamethasone. Am J Physiol Lung Cell Mol Physiol. 2003; 284:L738-L748. [PubMed: 12676764]

253. Haataja R, Hallman M. Surfactant proteins as genetic determinants of multifactorial pulmonary diseases. Ann Med. 2002; 34:324-333. [PubMed: 12452477]

254. Lin Z, Pearson C, Chinchilli V, Pietschmann SM, Luo J, Pison U, et al. Polymorphisms of human SP-A, SP-B, and SP-D genes: association of SP-B Thr131Ile with ARDS. Clin Genet. 2000; 58:181-191. [PubMed: 11076040]

255. Alcorn JL, Stark JM, Chiappetta CL, Jenkins G, Colasurdo GN. Effects of RSV infection on pulmonary surfactant protein SP-A in cultured human type II cells: contrasting consequences on SP-A mRNA and protein. Am J Physiol Lung Cell Mol Physiol. 2005; 289:L1113-L1122. [PubMed: 16055477]

256. Lofgren J, Ramet M, Renko M, Marttila R, Hallman M. Association between surfactant protein A gene locus and severe respiratory syncytial virus infection in infants. J Infect Dis. 2002; 185:283-289. [PubMed: 11807709]

257. Jack DL, Cole J, Naylor SC, Borrow R, Kaczmarski EB, Klein NJ, et al. Genetic polymorphism of the binding domain of surfactant protein-A2 increases susceptibility to meningococcal disease. Clin Infect Dis. 2006; 43:1426-1433. [PubMed: 17083016]

258. Madan T, Saxena S, Murthy KJ, Muralidhar K, Sarma PU. Association of polymorphisms in the collagen region of human SP-A1 and SP-A2 genes with pulmonary tuberculosis in Indian population. Clin Chem Lab Med. 2002; 40:1002-1008. [PubMed: 12476938]

259. Selman M, Lin HM, Montano M, Jenkins AL, Estrada A, Lin Z, et al. Surfactant protein A and B genetic variants predispose to idiopathic pulmonary fibrosis. Hum Genet. 2003; 113:542-550. [PubMed: 13680361]

260. Lahti M, Lofgren J, Marttila R, Renko M, Klaavuniemi T, Haataja R, et al. Surfactant protein D gene polymorphism associated with severe respiratory syncytial virus infection. Pediatr Res. 2002; 51:696-699. [PubMed: 12032263]

261. Leth-Larsen R, Garred P, Jensenius H, Meschi J, Hartshorn K, Madsen J, et al. A common polymorphism in the SFTPD gene influences assembly, function, and concentration of surfactant protein D. J Immunol. 2005; 174:1532-1538. [PubMed: 15661913]

262. Floros J, Lin HM, Garcia A, Salazar MA, Guo X, DiAngelo S, et al. Surfactant protein genetic marker alleles identify a subgroup of tuberculosis in a Mexican population. J Infect Dis. 2000; 182:1473-1478. [PubMed: 11023470]

263. Guo X, Lin HM, Lin Z, Montano M, Sansores R, Wang G, et al. Polymorphisms of surfactant protein gene A, B, D, and of SP-B-linked microsatellite markers in COPD of a Mexican population. Chest. 2000; 117:249S-250S. [PubMed: 10843936]

264. Guo X, Lin HM, Lin Z, Montano M, Sansores R, Wang G, et al. Surfactant protein gene A, B, and $\mathrm{D}$ marker alleles in chronic obstructive pulmonary disease of a Mexican population. Eur Respir J. 2001; 18:482-490. [PubMed: 11589345]

265. Reidy MF, Wright JR. Surfactant protein A enhances apoptotic cell uptake and TGF-beta1 release by inflammatory alveolar macrophages. Am J Physiol Lung Cell Mol Physiol. 2003; 285:L854L861. [PubMed: 12794007] 
266. Noah TL, Murphy PC, Alink JJ, Leigh MW, Hull WM, Stahlman MT, et al. Bronchoalveolar lavage fluid surfactant protein-A and surfactant protein-D are inversely related to inflammation in early cystic fibrosis. Am J Respir Crit Care Med. 2003; 168:685-691. [PubMed: 12829455]

267. Sims MW, Tal-Singer RM, Kierstein S, Musani AI, Beers MF, Panettieri RA, et al. Chronic obstructive pulmonary disease and inhaled steroids alter surfactant protein D (SP-D) levels: a cross-sectional study. Respir Res. 2008; 9:13. [PubMed: 18226251]

268. Tenner AJ, Robinson SL, Ezekowitz RA. Mannose binding protein (MBP) enhances mononuclear phagocyte function via a receptor that contains the $126,000 \mathrm{M}(\mathrm{r})$ component of the C1q receptor. Immunity. 1995; 3:485-493. [PubMed: 7584139]

269. Ghiran I, Barbashov SF, Klickstein LB, Tas SW, Jensenius JC, Nicholson-Weller A. Complement receptor 1/CD35 is a receptor for mannan-binding lectin. J Exp Med. 2000; 192:1797-1808. [PubMed: 11120776]

270. McGreal EP, Ikewaki N, Akatsu H, Morgan BP, Gasque P. Human C1qRp is identical with CD93 and the mNI-11 antigen but does not bind C1q. J Immunol. 2002; 168:5222-5232. [PubMed: 11994479] 


\section{INFORMATION FOR CATEGORY 1 CME CREDIT}

Credit can now be obtained, free for a limited time, by reading the review articles in this issue. Please note the following instructions.

\section{Method of Physician Participation in Learning Process}

The core material for these activities can be read in this issue of the Journal or online at the JACI Web site: www.jacionline.org. The accompanying tests may only be submitted online at www.jacionline.org. Fax or other copies will not be accepted.

\section{Date of Original Release}

November 2008. Credit may be obtained for these courses until October 31, 2010.

\section{Copyright Statement}

Copyright ( $2008-2010$. All rights reserved.

\section{Overall Purpose/Goal}

To provide excellent reviews on key aspects of allergic disease to those who research, treat, or manage allergic disease.

\section{Target Audience}

Physicians and researchers within the field of allergic disease.

\section{Accreditation/Provider Statements and Credit Designation}

The American Academy of Allergy, Asthma \& Immunology (AAAAI) is accredited by the Accreditation Council for Continuing Medical Education (ACCME) to provide continuing medical education for physicians. The AAAAI designates these educational activities for a maximum of 1 AMA PRA Category 1 Credit $^{\mathrm{TM}}$. Physicians should only claim credit commensurate with the extent of their participation in the activity.

\section{List of Design Committee Members}

Author: Angela Haczku, MD, PhD

\section{Activity Objectives}

1. To understand the unique structure of soluble pattern recognition receptors (collectins), their localization, and their functional versatility.

2. To understand the role of the lung collectins in pathogen recognition, airway defenses, and airway inflammation.

\section{Recognition of Commercial Support}

This CME activity is supported by an educational grant from Merck \& Co., Inc.

\section{Disclosure of Significant Relationships with Relevant Commercial Companies/ Organizations}

Angela Haczku has received grants from the National Institutes of Health, Sepracor, Centocor, and GlaxoSmithKline. 


\section{A Lamellar bodies}

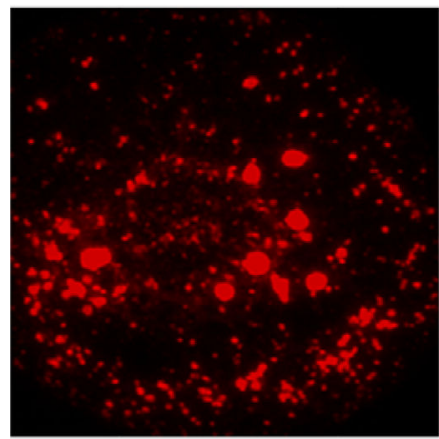

B

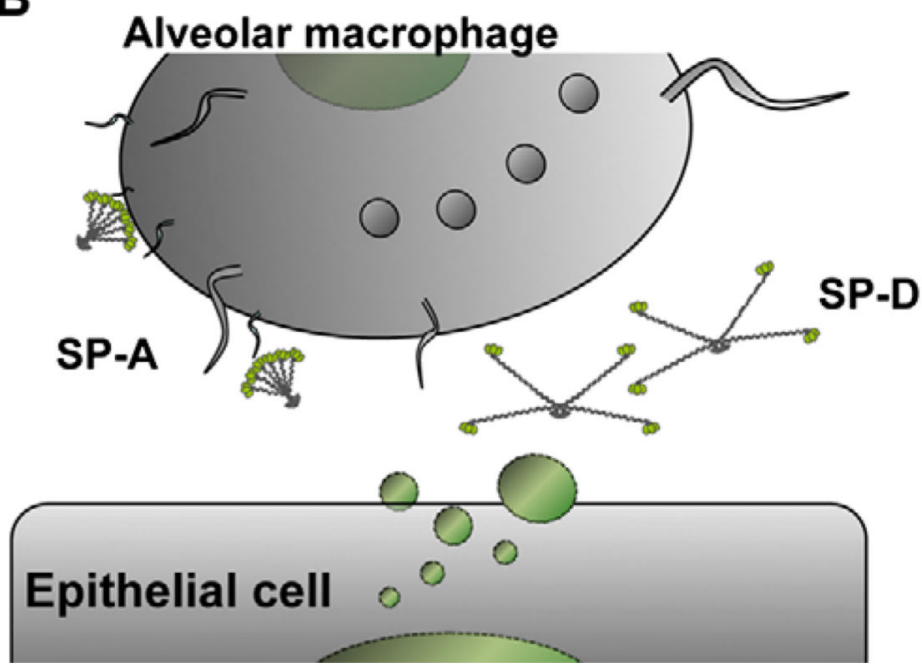

SP-D
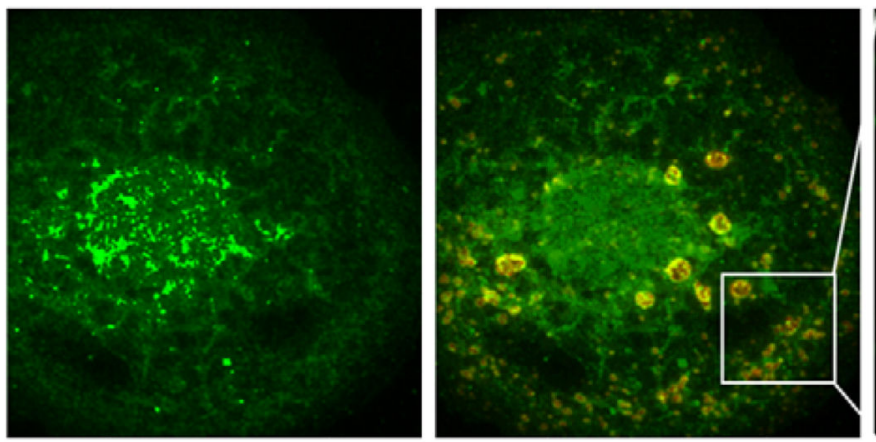

C

FIG. 1.

Lung collectins are produced by epithelial cells of the distal and proximal air spaces. A, Photomicrograph of a type II alveolar epithelial cell. Although the lung collectins have been localized to type II alveolar epithelial cells, immunocytochemistry studies indicate that they do not colocalize with lamellar bodies, the subcellular organelles responsible for storage and release of surfactant. Lamellar bodies were labeled with a monoclonal anti-ATP-binding cassette, subfamily A, member 3 antibody, 3C9 (Texas red, left panel). SP-D was labeled by a rabbit polyclonal antimouse SP-D (fluorescein isothiocyanate, second from left). The merged magnified image (right panel) illustrates that SP-D is scattered in the cytoplasm in a diffuse, reticular pattern and is localized outside the lamellar bodies. B, SP-A and SP-D are released onto mucosal surfaces to fulfill innate immune regulatory functions. Alveolar type II epithelial cells and Clara cells constitutively release SP-A and SP-D onto the luminal surface, where lung collectins associate with alveolar macrophages. $\mathbf{C}$, SP-D expression is prominent in both the alveoli and proximal airway epithelial cells. Collectins can be detected not only in the distal but also in the proximal airways, and their expression can be shifted during the inflammatory airway response to the site of inflammation involving Clara cells and goblet cells. The photomicrograph shows epithelial cells of a proximal airway and type 
II alveolar epithelial cells both positively labeled with a rabbit polyclonal anti-SP-D (fluorescein isothiocyanate). 
A

B
Hydrophobic (large aggregate) surfactant fraction
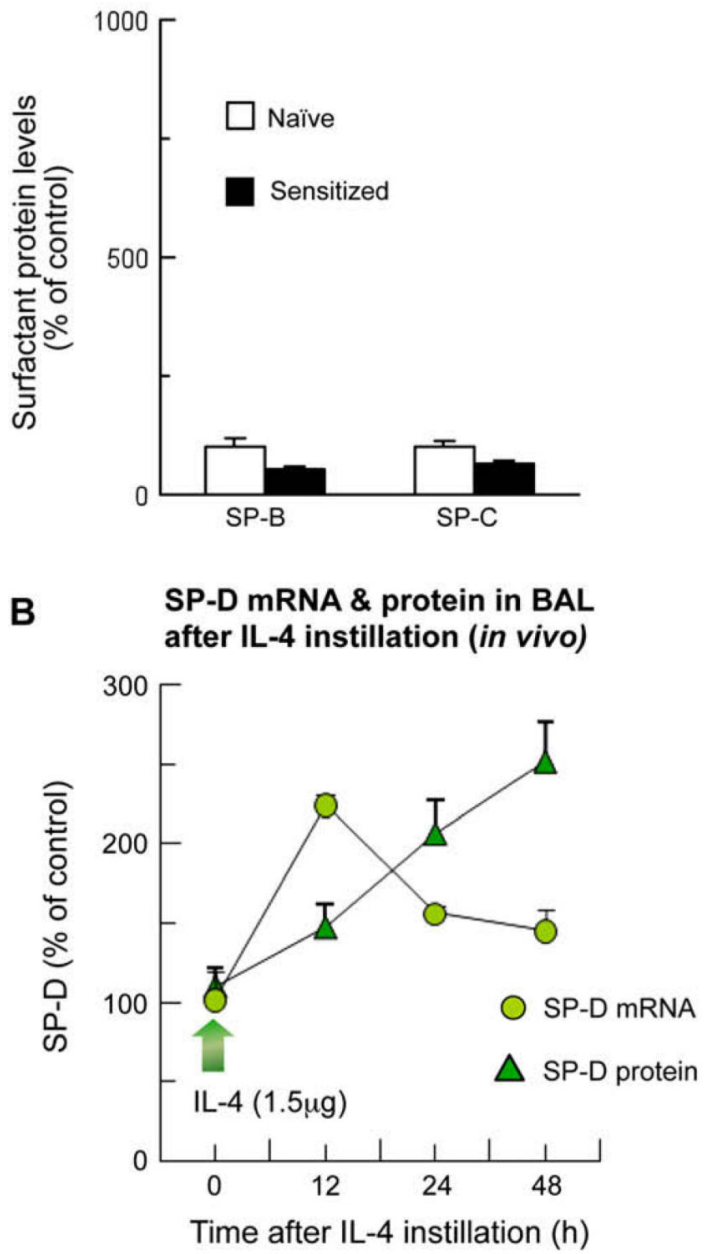

Hydrophylic (small aggregate) surfactant fraction

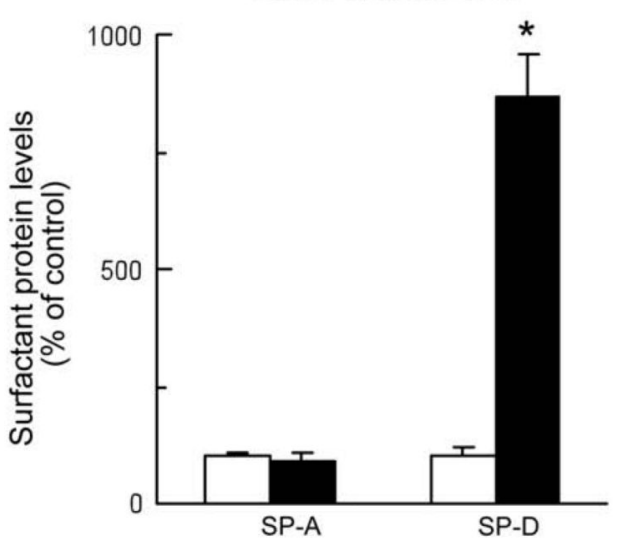

CP-D protein in type II alveolar
cells after IL-13 treatment (in vitro)

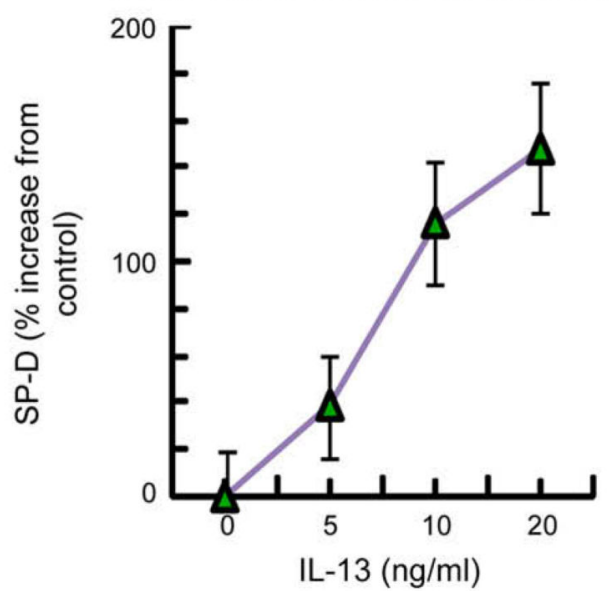

\section{Schematic structure of the murineSP-D promoter}

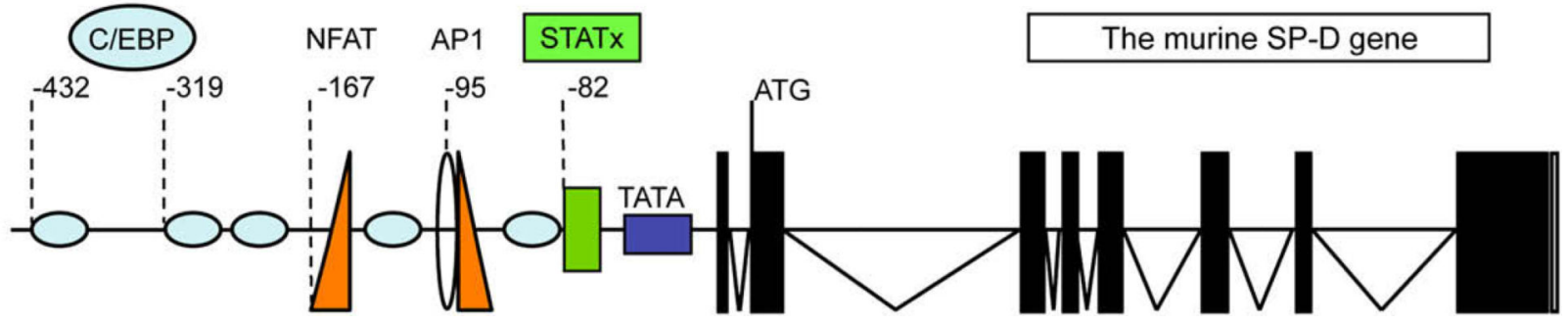

FIG. 2.

The SP-A and SP-D genes are under differential inflammatory regulation. A, Allergic sensitization and challenge with A fumigatus induced increased SP-D levels in the BAL fluid. Levels of SP-A did not change. SP-B and SP-C levels decreased by $~ 50 \%$. Western blot analysis of the small (SP-A, SP-D) and large (SP-B, SP-C) aggregate surfactant fractions. B, Murine recombinant IL-4 (1.5 $\mu \mathrm{g})$ induced a time-dependent increase in SP-D mRNA and protein expression in sensitized BALB/c mice in vivo. C, IL-13 (but not IFN- $\gamma$ [not shown]) induced intracellular SP-D protein increase in isolated type II alveolar 
epithelial cells in vitro. D, Schematic drawing of the murine SP-D promoter illustrates proximal location of C/EBP, NFAT, AP-1, and STAT binding sites. The proximal SP-D promoter shows an almost perfect alignment between mice and rats and with the exception of the STAT binding site, a close homology with the human promoter. 


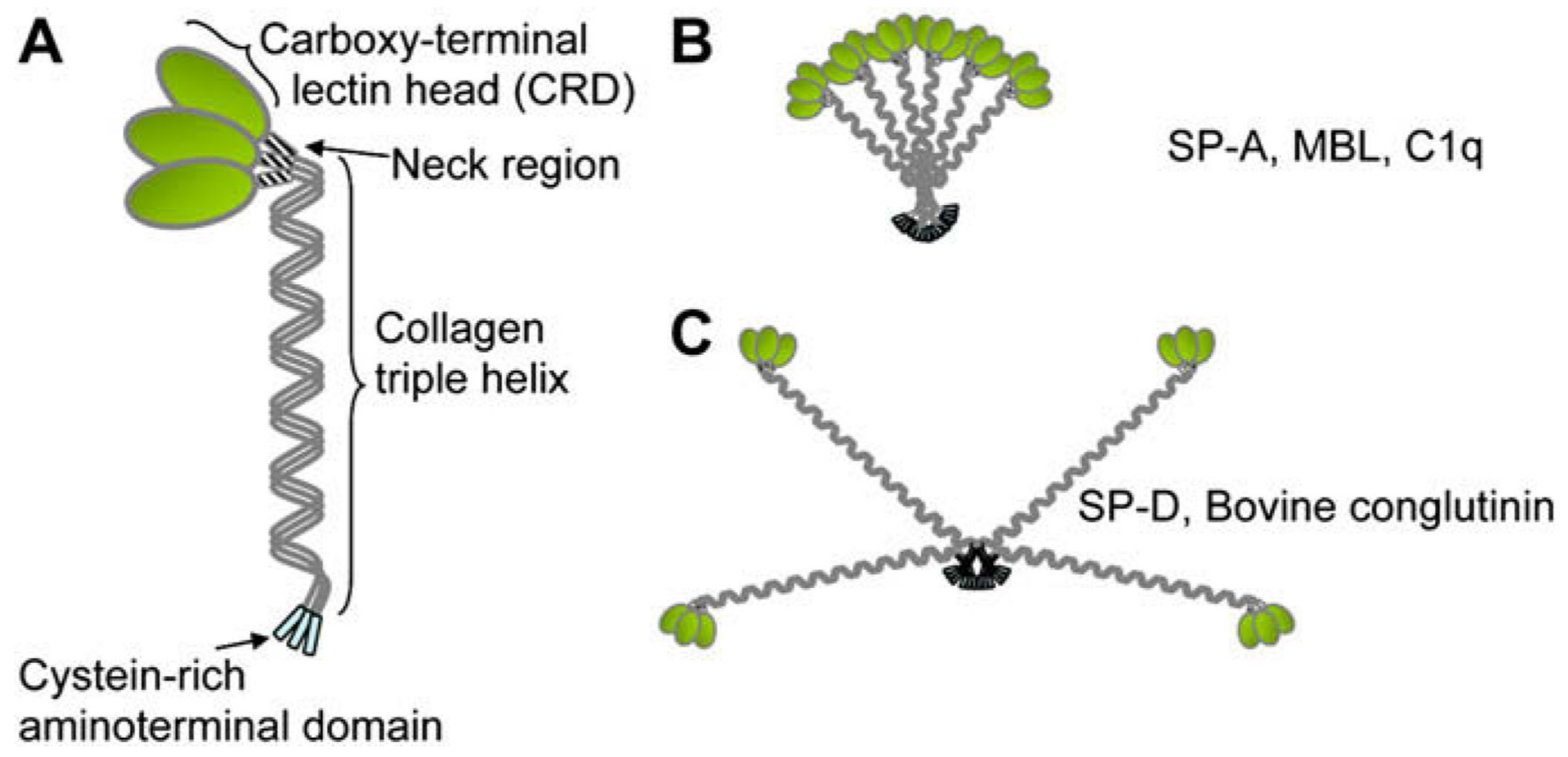

FIG. 3.

The collectin structure. A, The collectin triple helix. The collectins are assembled as trimeric subunits of a CRD, neck, and collagen region. B, SP-A, MBL and C1q have relatively short collagen domains, with a configuration resembling a bouquet of tulips. C, SP-D and conglutinin have a characteristic cruciform structure, assembled as tetramers of 3 identical polypeptides. 


\section{A Pathogen absence Direct immunosuppression "Head"} B Pathogen presence

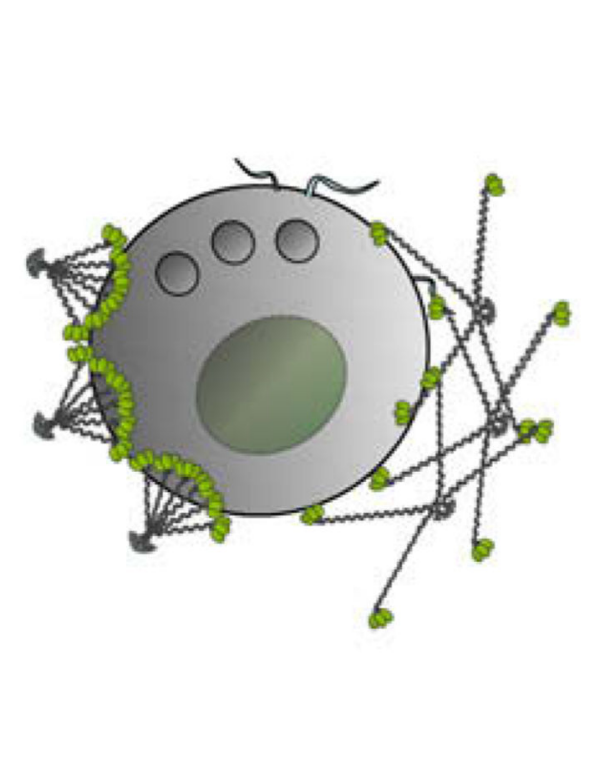
Host defense: opsonization "Tail"

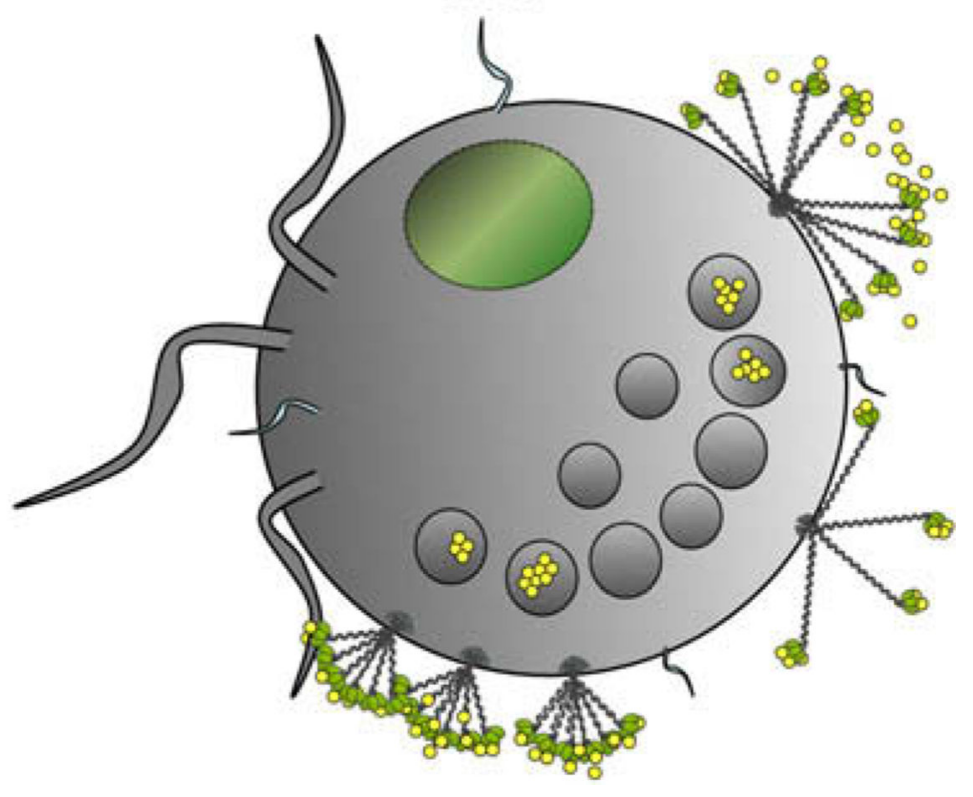

FIG. 4.

The "head or tail hypothesis"185: collectins are capable of differential binding through either their CRD or their collagen domain to cell membrane receptors and eliciting respective anti-inflammatory or proinflammatory signaling pathways. A, In the absence of pathogens, collectins bind to the innate immune cells with their head and deliver inhibitory signals. B, Collectin binding to pathogens via CRD and presenting the collagen tail to phagocytes induce proinflammatory cytokine release. $D C$, Dendritic cell. 

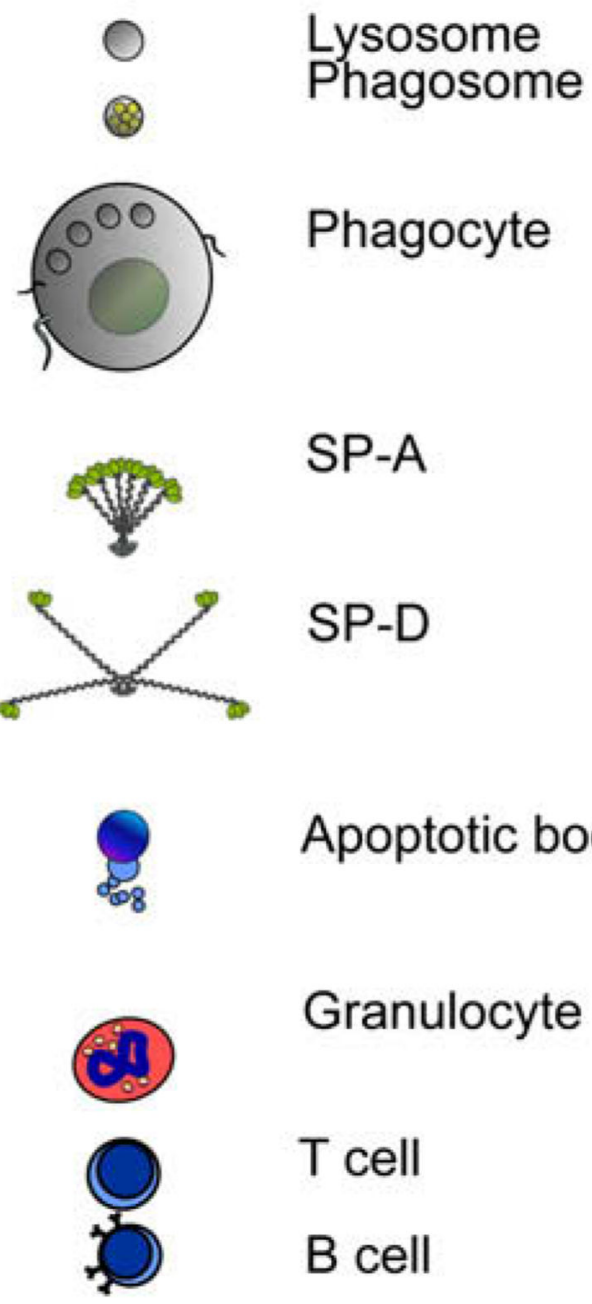

\author{
Granulocyte
}

T cell

$B$ cell

\section{Apoptotic bodies}

A

Suppression of dendritic cell maturation/activation

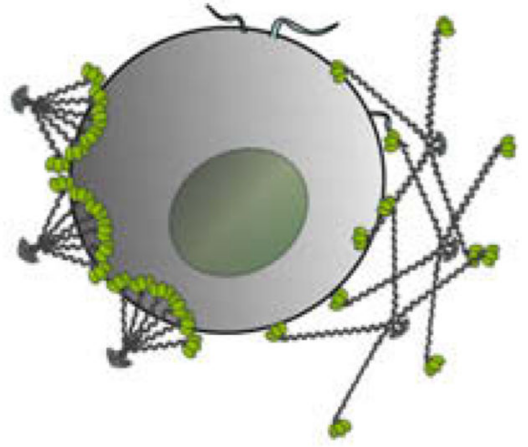

B

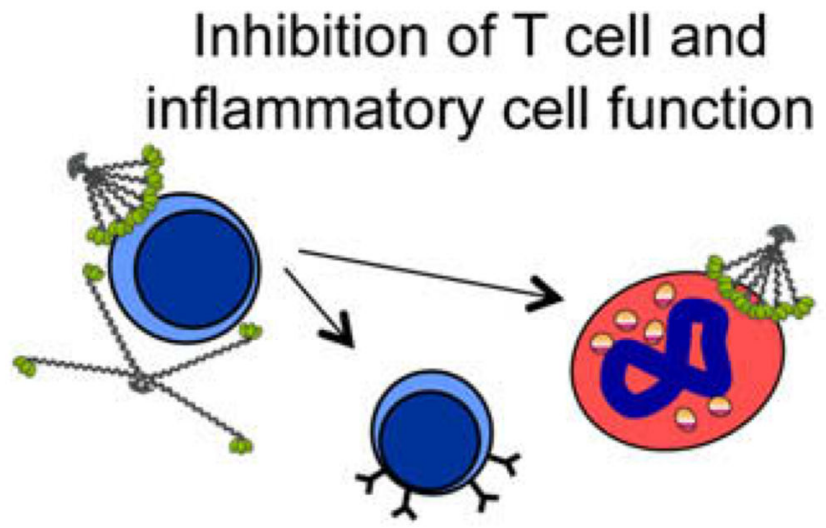

C

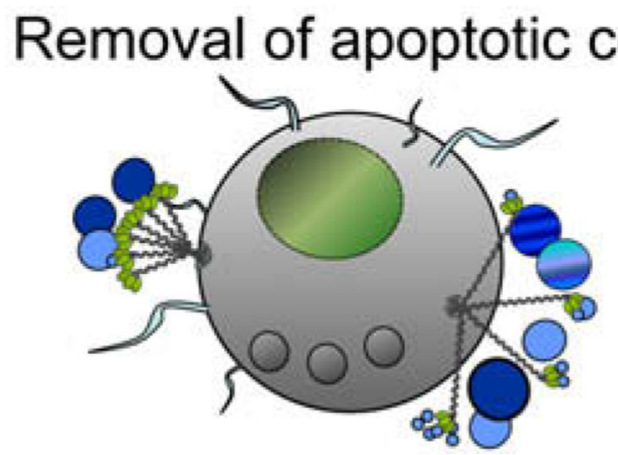

FIG. 5.

Lung collectins play an immunoprotective role during resolution of the inflammatory airway response at multiple levels. A, Collectins are capable of inhibiting dendritic cell maturation and activation. B, Collectins also inhibit T cells and the consequent activation of the adaptive immune response, immunoglobulin production by B cells and influx of granulocytes. Collectins inhibit mediator release directly from inflammatory cells. $\mathbf{C}$, Collectins facilitate removal of apoptotic cells during resolution of the inflammatory response. 


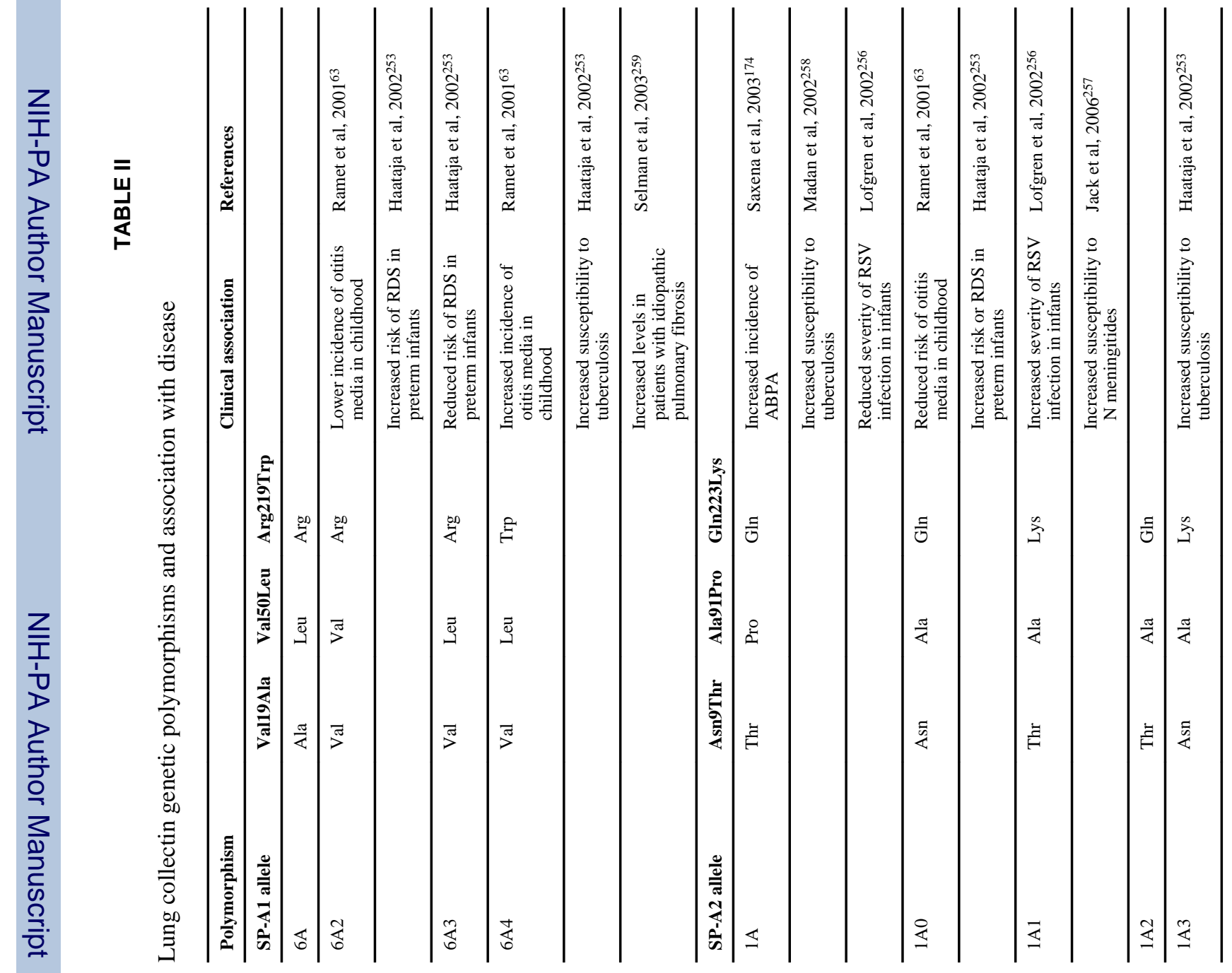




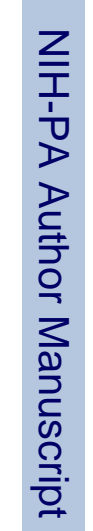

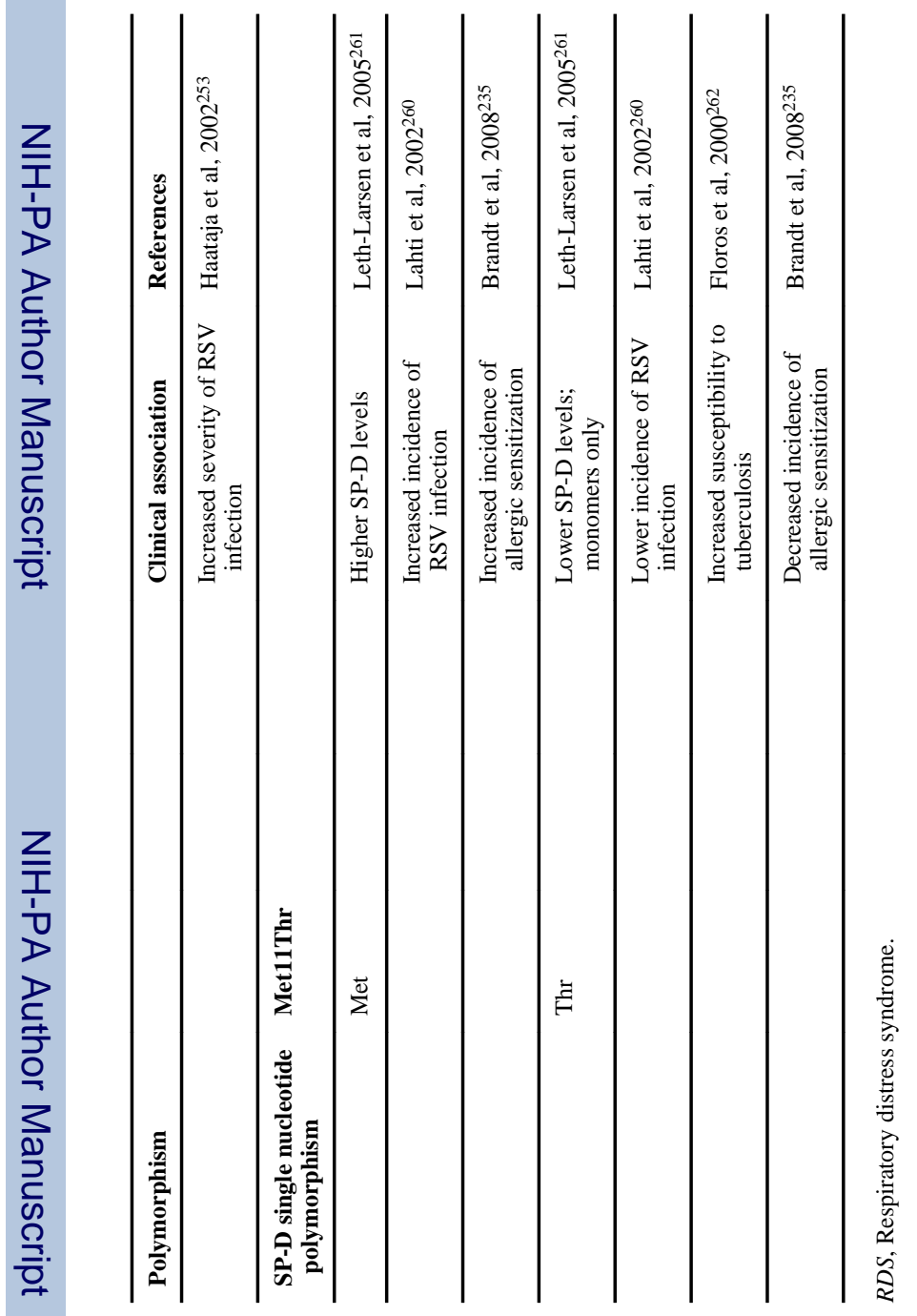

J Allergy Clin Immunol. Author manuscript; available in PMC 2014 July 15. 